\title{
Multidrug Resistance Protein 1 (MRP1/ABCC1)-Mediated Cellular Protection and Transport of Methylated Arsenic Metabolites Differs between Human Cell Lines ${ }^{\circledR}$
}

\author{
Mayukh Banerjee, ${ }^{1}$ Gurnit Kaur, Brayden D. Whitlock, Michael W. Carew, X. Chris Le, \\ and Elaine M. Leslie
}

Departments of Physiology (M.B., B.D.W., M.W.C., E.M.L.) and Laboratory Medicine and Pathology (G.K., X.C.L., E.M.L.) and Membrane Protein Disease Research Group (M.B., G.K., B.D.W., M.W.C., E.M.L.), University of Alberta, Edmonton, Alberta, Canada

Received November 21, 2017; accepted May 9, 2018

\section{ABSTRACT}

The ATP-binding cassette (ABC) transporter multidrug resistance protein 1 (MRP1/ABCC1) protects cells from arsenic (a proven human carcinogen) through the cellular efflux of arsenic triglutathione [As(GS) $]_{3}$ and the diglutathione conjugate of monomethylarsonous acid [MMA (GS)2]. Previously, differences in MRP1 phosphorylation (at Y920/S921) and $\mathrm{N}$-glycosylation (at N19/N23) were associated with marked differences in As(GS) ${ }_{3}$ transport kinetics between HEK293 and HeLa cell lines. In the current study, cell line differences in MRP1-mediated cellular protection and transport of other arsenic metabolites were explored. MRP1 expressed in HEK293 cells reduced the toxicity of the major urinary arsenic metabolite dimethylarsinic acid (DMA ${ }^{\mathrm{V}}$ ), and HEKWT-MRP1-enriched vesicles transported DMA ${ }^{\mathrm{V}}$ with high apparent affinity and capacity $\left(K_{\mathrm{m}} 0.19 \mu \mathrm{M}, V_{\max } 342 \mathrm{pmol} \cdot \mathrm{mg}^{-1}\right.$ protein $\left.\cdot \mathrm{min}^{-1}\right)$. This is the first report that MRP1 is capable of exporting DMA ${ }^{\mathbf{v}}$, critical for preventing highly toxic dimethylarsinous acid formation. In contrast, DMA ${ }^{\mathrm{V}}$ transport was not detected using HeLa-WT-MRP1 membrane vesicles. MMA(GS) ${ }_{2}$ transport by HeLa-WT-MRP1 vesicles had a greater than threefold higher $V_{\max }$ compared with HEKWT-MRP1 vesicles. Cell line differences in DMA ${ }^{\mathrm{V}}$ and MMA(GS) transport were not explained by differences in phosphorylation at $\mathrm{Y920/S921.} \mathrm{DMA}^{\mathrm{V}}$ did not inhibit, whereas MMA(GS) $)_{2}$ was an uncompetitive inhibitor of $A s(G S)_{3}$ transport, suggesting that DMA ${ }^{v}$ and MMA(GS) ${ }_{2}$ have nonidentical binding sites to As(GS) ${ }_{3}$ on MRP1. Efflux of different arsenic metabolites by MRP1 is likely influenced by multiple factors, including cell and tissue type. This could have implications for the impact of MRP1 on both tissue-specific susceptibility to arsenic-induced disease and tumor sensitivity to arsenic-based therapeutics.

\section{Introduction}

Arsenic is a proven human carcinogen, causing lung, skin, and bladder tumors (IARC, 2012). Chronic arsenic exposure is associated with increased incidences of kidney and liver tumors and a myriad of noncancerous adverse health effects (Platanias, 2009; IARC, 2012; Naujokas et al., 2013). Millions of people worldwide are exposed to levels of arsenic above the World Health Organization acceptable level of $10 \mu \mathrm{g} / \mathrm{l}$, predominantly through the consumption of groundwater naturally contaminated with inorganic arsenic [arsenite $\left(\mathrm{As}^{\mathrm{III}}\right)$ and arsenate $\left(\mathrm{As}^{\mathrm{V}}\right)$ ] (Rahman et al., 2009). In addition to environmental

This work was supported by the Canadian Institutes of Health Research [CIHR Grant MOP-272075]. M.B. was supported by an Alberta Cancer Foundation Cancer Research Postdoctoral Fellowship award. X.C.L. holds the Canada Research Chair in Bioanalytical Technology and Environmental Health. G.K. holds a Queen Elizabeth II doctoral scholarship and a Medical Sciences Graduate Program Scholarship from the University of Alberta. E.M.L. was an Alberta Innovates Health Solutions Scholar and a CIHR New Investigator.

${ }^{1}$ Current affiliation: Department of Pharmacology and Toxicology, University of Louisville, Kentucky.

https://doi.org/10.1124/dmd.117.079640.

S This article has supplemental material available at dmd.aspetjournals.org. exposures, arsenic trioxide is used clinically in the treatment of acute promyelocytic leukemia and is in clinical trials for the treatment of other hematologic and solid tumors (Kritharis et al., 2013; Ally et al., 2016; Cicconi and Lo-Coco, 2016; Falchi et al., 2016). Other arsenic compounds are also in clinical trials for the treatment of various cancers (Khairul et al., 2017). Thus, understanding the cellular handling of arsenic is critical for the development of therapeutics to treat chronic arsenic exposure and to maximize the clinical effectiveness of arsenic based drugs.

Cellular uptake of arsenic has been recently reviewed (Mukhopadhyay et al., 2014; Roggenbeck et al., 2016). Once inside most mammalian cells, arsenic undergoes extensive methylation (Vahter, 1999; Drobna et al., 2010). In humans, the four major methylation products are monomethylarsonic acid $\left(\mathrm{MMA}^{\mathrm{V}}\right)$, monomethylarsonous acid $\left(\mathrm{MMA}^{\mathrm{III}}\right)$, dimethylarsinic acid $\left(\mathrm{DMA}^{\mathrm{V}}\right)$, and dimethylarsinous acid (DMA ${ }^{\mathrm{III}}$ ) (Thomas et al., 2007). Arsenic methylation has a significant impact on its toxicity, tissue distribution, and retention (Thomas et al., 2004, 2007; Wang et al., 2015). Although arsenic methylation results in an increased rate of arsenic whole body clearance (Drobna et al., 2009, 2010; Hughes et al., 2010) and reduces susceptibility to acute arsenic toxicity (Yokohira et al., 2010, $2011)$, trivalent methylated forms of arsenic $\left(\mathrm{MMA}^{\mathrm{III}}\right.$ and $\left.\mathrm{DMA}^{\mathrm{III}}\right)$ are considered bioactivation products because they are more reactive

ABBREVIATIONS: ABC, ATP-binding cassette; $\mathrm{As}^{\mathrm{III}}$, arsenite; $\mathrm{As}^{\mathrm{V}}$, arsenate; $\mathrm{As}(\mathrm{GS})_{3}$, arsenic triglutathione; $\mathrm{DMA}^{\mathrm{III}}$, dimethylarsinous acid; $\mathrm{DMA} \mathrm{V}^{\mathrm{V}}$, dimethylarsinic acid; GSH, glutathione; HEK293, human embryonic kidney 293; IC 50 , half-maximal inhibitory concentration; MMA"I', monomethylarsonous acid; $\mathrm{MMA}^{\mathrm{V}}$, monomethylarsonic acid; $\mathrm{MMA}(\mathrm{GS})_{2}$, monomethylarsenic diglutathione; MRP, multidrug resistance protein; MSD, membrane spanning domain; NBD, nucleotide binding domain; PIC, phosphatase inhibitor cocktail; WT, wild type. 
metabolites than As ${ }^{\text {III }}$ (Petrick et al., 2000; Styblo et al., 2000; Mass et al., 2001; Kligerman et al., 2003; Moe et al., 2016).

In addition to methylation, arsenic can be conjugated with reduced glutathione (GSH/GS) (Leslie, 2012). Arsenic triglutathione [As(GS) 3 ] and the diglutathione conjugate of the highly toxic $\mathrm{MMA}^{\mathrm{III}}\left[\mathrm{MMA}(\mathrm{GS})_{2}\right]$ have been isolated from rat bile and mouse urine, thus these two As-GSH complexes are formed physiologically and account for a major fraction of arsenic in urine and bile (Kala et al., 2000, 2004; Suzuki et al., 2001; Cui et al., 2004; Bu et al., 2011). The ATP-binding cassette (ABC) transporter multidrug resistance protein 1 (MRP1, gene symbol $A B C C 1$ ), along with the related MRP2 and MRP4 (ABCC2 and ABCC4, respectively) mediate the cellular export of multiple methylated and/or glutathionylated metabolites of arsenic (Kala et al., 2000, 2004; Leslie et al., 2004; Carew and Leslie, 2010; Carew et al., 2011; Banerjee et al., 2014; Shukalek et al., 2016).

MRP1 is a $190-\mathrm{kDa}$ phosphoglycoprotein with three polytopic membrane spanning domains (MSDs) and two nucleotide binding domains (NBDs) arranged as MSD0-MSD1-NBD1-MSD2-NBD2 (Cole, 2014). MRP1 confers resistance to a chemically diverse array of anti-cancer drugs and is involved in the cellular export of physiologic compounds including GSH, glutathione disulfide, $17 \beta$-estradiol 17 - $\left(\beta\right.$-D-glucuronide), and leukotriene $\mathrm{C}_{4}$ (Cole, 2014). Furthermore, MRP1 transports a variety of xenobiotics often conjugated to GSH, glucuronate, or sulfate (Jedlitschky et al., 1996; Loe et al., 1996a,b; Leslie et al., 2005). Included in this list are the arsenic metabolites $\mathrm{As}(\mathrm{GS})_{3}$ and MMA $(\mathrm{GS})_{2}$, the glutathionylated forms of inorganic arsenic ( $\mathrm{As}^{\mathrm{III}}$ and $\mathrm{As}^{\mathrm{V}}$ ), and MMA ${ }^{\mathrm{III}}$, respectively (Leslie et al., 2004; Carew et al., 2011).

Interestingly, $\mathrm{As}(\mathrm{GS})_{3}$ is transported by MRP1 expressed in HEK293 cells with markedly different kinetics than by MRP1 expressed in HeLa cells (Shukalek et al., 2016). Further investigation revealed that MRP1 affinity and capacity for $\mathrm{As}(\mathrm{GS})_{3}$ was associated with the phosphorylation status of two residues in the linker region between NBD1 and MSD2 (Y920 and S921). Furthermore, the glycosylation status of two residues in the amino terminus (N19 and N23) influenced the stability of Y920 and/or S921 phosphorylation (Shukalek et al., 2016). Given this cell line difference, the first objective of the current study was to determine differences in arsenical cytotoxicity between the HEK-MRP1 and HeLa-MRP1 cell lines. The second objective was to use MRP1-enriched membrane vesicles isolated from HEK and HeLa cells to determine the cell line differences in MRP1 transport function. The third objective was to investigate the influence of Y920/S921 phosphorylation on the ability of HEK-MRP1-enriched membrane vesicles to transport arsenic metabolites in addition to $\mathrm{As}(\mathrm{GS})_{3}$.

\section{Materials and Methods}

Materials. Carrier-free ${ }^{73} \mathrm{As}^{\mathrm{V}}(158 \mathrm{Ci} / \mathrm{mol})$ was purchased from Los Alamos Meson Production Facility (Los Alamos, NM). Tris base, GSH, ATP, AMP, sucrose, $\mathrm{DMA}^{\mathrm{V}}$ ( $>99 \%$ purity), $\mathrm{MgCl}_{2}$, creatine kinase, $\mathrm{GSH}$ reductase, creatine phosphate, NADPH, sodium (meta)-arsenite $\left[\mathrm{Na}_{2} \mathrm{AsO}_{2}\right]$ ( $>99 \%$ pure), $\mathrm{As}^{\mathrm{V}}\left(>98 \%\right.$ purity), sodium metabisulfite $\left[\mathrm{Na}_{2} \mathrm{~S}_{2} \mathrm{O}_{5}\right]$, and sodium thiosulfate $\left[\mathrm{Na}_{2} \mathrm{~S}_{2} \mathrm{O}_{3}\right]$ were from Sigma-Aldrich (Oakville, Canada). Protease inhibitor cocktail tablets (Complete, Mini, EDTA-free) and PhosSTOP phosphatase inhibitor cocktail (PIC) tablets were purchased from Roche Applied Science (Laval, Canada). Phenylmethylsulfonyl fluoride was from Bioshop Canada Inc. (Burlington, Canada). Suprapur nitric acid was purchased from Merck (Darmstadt, Germany). MMA ${ }^{\mathrm{III}}$ and $\mathrm{DMA}^{\mathrm{III}}$ in the form diiodomethylarsine $\left(\mathrm{CH}_{3} \mathrm{AsI}_{2}\right)$ and iododimethylarsine $\left(\left[\mathrm{CH}_{3}\right]_{2} \mathrm{AsI}\right)$, respectively, were synthesized as previously described (Cullen et al., 2016) and were at least 99\% pure as confirmed by NMR analysis. The rat monoclonal antibody (mAb) MRPr1 was from Novus Biologicals (Littleton, $\mathrm{CO}$ ), while rabbit anti- $\mathrm{Na}^{+} / \mathrm{K}^{+}$ATPase $(\mathrm{H}-300)$ was purchased from Santa Cruz Biotechnology, Inc. (Santa Cruz, CA).
Cell Lines and Stable Transfection. HEK293T cells were obtained from the American Type Culture Collection (Rockville, MD) and maintained in Dulbecco's modified Eagle's medium with 7.5\% fetal bovine serum. HeLa and HEK293 cell lines stably expressing the empty pcDNA3.1(-) vector (HeLa-vector) and/or pcDNA3.1(-)-MRP1 (HeLa-MRP1 and HEK-MRP1) were gifts from Dr. Susan P.C. Cole (Queen's University, Kingston, Canada) and generated as described previously (Ito et al., 2001; Conseil and Cole, 2013). The HEK-vector expressing cell line (HEK-V4) was generated as described previously (Banerjee et al., 2014). HeLa stables were maintained in Roswell Park Memorial Institute (RPMI)-1640 medium with 5\% calf serum and $600 \mu \mathrm{g} / \mathrm{ml} \mathrm{G} 418$ (Geneticin). HEK293 stables were maintained in Dulbecco's modified Eagle's medium with $7.5 \%$ fetal bovine serum and $600 \mu \mathrm{g} / \mathrm{ml} \mathrm{G418.} \mathrm{Stable} \mathrm{cell} \mathrm{lines} \mathrm{were} \mathrm{checked} \mathrm{for} \mathrm{the} \mathrm{proportion} \mathrm{of}$ cells expressing MRP1 by flow cytometry (BD FACS Calibur, Cross Cancer Institute) using the MRP1-specific MAb MRPr1, as described previously (Hipfner et al., 1994; Leslie et al., 2003). Populations of less than $80 \%$ were not used in experiments.

Cytotoxicity Testing. The cytotoxicity of five arsenic species was measured using HEK-vector, HEK-MRP1, HeLa-vector, and HeLa-MRP1 as previously described (Carew et al., 2011). Briefly, cells were seeded in 96-well plates at $1 \times$ $10^{4}$ cells/well and grown for 24 hours. In quadruplicate, cells were treated with $\mathrm{As}^{\mathrm{III}}(0.01-300 \mu \mathrm{M}), \mathrm{As}^{\mathrm{V}}(0.05-5000 \mu \mathrm{M}), \mathrm{MMA}^{\mathrm{III}}(0.03-30 \mu \mathrm{M}), \mathrm{DMA}^{\mathrm{III}}$ $(0.01-300 \mu \mathrm{M})$, or $\mathrm{DMA}^{\mathrm{V}}(0.01-30 \mathrm{mM})$ for 72 hours. These doses were experimentally determined to range from nontoxic to causing complete loss of viability over 72 hours. The $\mathrm{pH}$ of $\mathrm{DMA}^{\mathrm{V}}$ was adjusted to $\mathrm{pH} 7.4$ prior to treating cells. Cytotoxicity was determined using the tetrazolium-based MTS assay [CellTiter 96 Aqueous Non-Radioactive Cell Proliferation Assay (Promega, Madison, WI)], according to the manufacturer's instructions. The $\mathrm{IC}_{50}$, defined as the concentration of arsenical that resulted in half the maximal toxic effect, for each arsenical was determined for HEK-MRP1 and HEK-vector cells using the sigmoidal dose-response equation in GraphPad Prism (GraphPad Software, La Jolla, CA). Relative resistance values (equivalent to relative protection), defined as the ratio of the $\mathrm{IC}_{50}$ value in HEK-MRP1 to that in HEK-vector, were determined for each arsenical tested.

Site-Directed Mutagenesis. Mutants of MRP1 (S905A-, S915A-, S916A-, S917A-, Y920F-, S921A-, Y920F/S921A-, Y920E/S921E-, and T931A-MRP1) were generated previously (Shukalek et al., 2016). In addition, several new potential phosphorylation mutants (S916E-, S918A-, S919A-, and S919E-MRP1) were generated using the QuikChange II XL site-directed mutagenesis kit (Stratagene; Agilent Technologies, Santa Clara, CA). pcDNA3.1(-)-MRP1 was used as the PCR template, and mutagenesis was carried out according to the manufacturer's instructions using mutagenic primers from Integrated DNA Technology (Coralville, IA); sequences are available upon request. The incorporation of desired mutations was confirmed by DNA sequencing (Molecular Biology Servicing Unit, University of Alberta, Edmonton, Canada).

Expression of Wild-Type and Mutant Forms of MRP1 in HEK293T Cells, Preparation of Membrane Vesicles, and Immunoblots. HEK293T cells were transfected using the calcium-phosphate method as described previously (Carew and Leslie, 2010) and incubated for 48- to 72-hours posttransfection. For membrane vesicle preparations, WT and MRP1 mutant-transfected cells were collected by centrifugation, layered with Tris sucrose buffer ( $50 \mathrm{mM}$ Tris, $\mathrm{pH}$ 7.4, $250 \mathrm{mM}$ sucrose $)$ containing $\mathrm{CaCl}_{2}(0.25 \mathrm{mM})$, EDTA-free protease inhibitors, and where indicated, phosSTOP PIC, and cell pellets stored at $-80^{\circ} \mathrm{C}$ until plasma membrane-enriched vesicles were isolated as described previously (Carew and Leslie, 2010). Expression of WT and MRP1 mutants were confirmed by immunoblotting as described previously (Shukalek et al., 2016), using the MRPr1 antibody (1:10,000 dilution). Blots were also probed for $\mathrm{Na}^{+} / \mathrm{K}^{+}$ATPase as a loading control using the $\mathrm{Na}^{+} / \mathrm{K}^{+}$-ATPase-specific antibody H-300 (1:10,000 dilution), except in the case of comparison of MRP1 levels between the two different cell lines (the $\mathrm{Na}^{+} / \mathrm{K}^{+}$-ATPase level was found to be different). Thus, blots were stained with Coomassie blue and normalized to total protein levels in each lane. Relative levels of MRP1 were quantified using Image J Software (National Institutes of Health, Bethesda, MD) and/or ImageLab Software (Bio-Rad, Hercules, CA).

$\operatorname{MMA}(G S)_{2}$, DMA $^{\mathrm{v}}$, and As(GS $)_{3}$ Vesicular Transport Assays. Reduction of arsenate $\left[{ }^{73} \mathrm{As}^{\mathrm{V}}\right]$ into arsenite $\left[{ }^{73} \mathrm{As}{ }^{\mathrm{III}}\right]$ and subsequent synthesis of ${ }^{73} \mathrm{As}(\mathrm{GS})_{3}$ from ${ }^{73} \mathrm{As}{ }^{\mathrm{III}}$ and GSH were carried out as described previously (Reay and Asher, 1977; Shukalek et al., 2016). MMA(GS) $)_{2}$ was synthesized from $\mathrm{MMA}^{\mathrm{III}}$ and GSH as described previously (Carew et al., 2011; Banerjee et al., 
2014). Vesicular transport was carried out in triplicate for each substrate, employing previously described methods (Carew et al., 2011; Banerjee et al., 2014; Shukalek et al., 2016). The amount of ${ }^{73} \mathrm{As}(\mathrm{GS})_{3}$ transported was quantified using liquid scintillation counting, as described previously (Leslie et al., 2004; Shukalek et al., 2016). The amount of MMA(GS $)_{2}$ and DMA ${ }^{\mathrm{V}}$ transported was quantified by inductively coupled plasma mass spectrometry using the standard addition method, as described previously (Banerjee et al., 2014). ATP-dependent transport was calculated by subtracting transport in the presence of AMP from transport in the presence of ATP, and data are expressed as picomoles or nanomoles $\mathrm{As}(\mathrm{GS})_{3}, \mathrm{MMA}(\mathrm{GS})_{2}$, or $\mathrm{DMA}^{\mathrm{V}}$ transported per milligram protein per minute.

The linear range of DMA ${ }^{\mathrm{V}}$ transport was determined by incubating the HEK-WT-MRP1 or HEK-vector membrane vesicles with DMA ${ }^{\mathrm{V}}(1 \mu \mathrm{M})$ in transport buffer at $37^{\circ} \mathrm{C}$ for the indicated time points. Kinetic parameters were determined by measuring the initial rate of $\mathrm{DMA}^{\mathrm{V}}$ and $\mathrm{MMA}(\mathrm{GS})_{2}$ transport at eight different substrate concentrations [0.1-2.5 $\mu \mathrm{M}$ for $\mathrm{DMA}^{\mathrm{V}}$ and $1-200 \mu \mathrm{M}$ for $\mathrm{MMA}(\mathrm{GS})_{2}$ ] at 20 seconds and 1 minute, respectively. Curve fitting was done by nonlinear regression analysis using GraphPad Prism 6 software.

The ability of DMA ${ }^{\mathrm{V}}$ and MMA(GS) $)_{2}$ to inhibit ${ }^{73} \mathrm{As}(\mathrm{GS})_{3}$ transport was first characterized by using a fixed concentration of ${ }^{73} \mathrm{As}(\mathrm{GS})_{3}(1 \mu \mathrm{M}, 40 \mathrm{nCi})$ in the presence of increasing concentrations of $\mathrm{DMA}^{\mathrm{V}}(0.04$ and $1000 \mu \mathrm{M})$ or MMA $(\mathrm{GS})_{2}(0.01-300 \mu \mathrm{M})$. The conditions for the synthesis of $\mathrm{As}(\mathrm{GS})_{3}$ resulted in the presence of $3 \mathrm{mM} \mathrm{GSH}$ in transport reactions (Leslie et al., 2004). Thus, $\mathrm{As}(\mathrm{GS})_{3}$ inhibition experiments were completed under plus GSH conditions. This is important because the in vitro inhibition of MRP1 by certain compounds can be enhanced by physiologic concentrations of GSH (Cole and Deeley, 2006). $\mathrm{IC}_{50}$ values were calculated for MMA(GS $)_{2}$ inhibition using GraphPad Prism 6 Software [nonlinear regression $\log$ (inhibitor) vs. response variable slope (4 parameters)]. To determine the mode of inhibition of ${ }^{73} \mathrm{As}(\mathrm{GS})_{3}$ by MMA $(\mathrm{GS})_{2}$, the $K_{\mathrm{i}}$ of MMA(GS $)_{2}$ was determined by performing ${ }^{73} \mathrm{As}(\mathrm{GS})_{3}$ $(0.1-20 \mu \mathrm{M}, 40-100 \mathrm{nCi})$ transport in the presence of three different MMA (GS) $)_{2}$ concentrations $(5,10$, and $15 \mu \mathrm{M}$ ), as described previously (Leslie et al., 2004).

All transport data were normalized as needed to correct for any difference in level of HeLa-WT-MRP1 or mutant MRP1 expressed in HEK cells relative to HEK-WT-MRP1 as determined by immunoblotting of each membrane vesicle preparation. Positive control transport experiments using MMA(GS) $)_{2}$ or As(GS) were run for each vesicle preparation, as described above and previously (Leslie et al., 2004; Carew et al., 2011).

\section{Results}

MRP1 Expressed in HEK293 Cells Decreases the Cytotoxicity of As $^{\text {III }}$ As ${ }^{\mathbf{V}}$, MMA $^{\text {III }}$, and DMA ${ }^{\mathbf{v}}$. Previously we showed that MRP1 stably expressed in HeLa cells reduced the toxicity of $\mathrm{As}^{\mathrm{III}}, \mathrm{As}^{\mathrm{V}}$, and $\mathrm{MMA}^{\mathrm{III}}$, but not $\mathrm{MMA}^{\mathrm{V}}$, DMA ${ }^{\mathrm{III}}$, or $\mathrm{DMA}^{\mathrm{V}}$, relative to HeLa cells expressing empty vector alone (Carew et al., 2011). Given that we recently reported substantial differences in the transport of $\mathrm{As}(\mathrm{GS})_{3}$ between MRP1-enriched membrane vesicles isolated from HEK293 and HeLa cells (Shukalek et al., 2016), differences in arsenical cytotoxicity between the two cell lines were investigated. Thus, the cytotoxicity of five of these arsenicals (As ${ }^{\mathrm{III}}, \mathrm{As}^{\mathrm{V}}, \mathrm{MMA}^{\mathrm{III}}, \mathrm{DMA}^{\mathrm{III}}$, and $\mathrm{DMA}^{\mathrm{V}}$ ) in HEK-MRP1 and HEK-vector cell lines was determined in parallel with HeLa-MRP1 and HeLa-vector for comparison [Fig. 1; Table 1, and (Carew et al., 2011)].

The arsenic compounds that HEK-MRP1 cells conferred resistance to (relative to HEK-vector) were the same as the HeLa cell line pair (Fig. 1, A-C; Table 1), except that HEK-MRP1 conferred a significantly increased level of resistance against $\mathrm{DMA}^{\mathrm{V}}$ (relative resistance value of $1.4, P<0.05$ ) [Fig. 1D; Table 1, and (Carew et al., 2011)]. In addition, HEK-MRP1 cells had a relative resistance of 9.2 against $\mathrm{As}^{\mathrm{V}}$ (Fig. 1B; Table 1), whereas HeLa-MRP1 cells had a relative resistance of only 2.1 [Table 1 and (Carew et al., 2011)]. These results led us to characterize the cell line differences for $\mathrm{DMA}^{\mathrm{V}}$ and $\mathrm{As}^{\mathrm{V}}$ transport using MRP1-enriched membrane vesicles. Furthermore, although resistance to $\mathrm{MMA}^{\mathrm{III}}$ was conferred by both HEK-MRP1 and HeLa-MRP1 cell lines [Fig. 1C; Table 1 and (Carew et al., 2011)], differences in transport characteristics between membrane vesicles prepared from these cell lines were also investigated for $\mathrm{MMA}(\mathrm{GS})_{2}$.

Transport of DMA ${ }^{\mathbf{v}}$ by MRP1-Enriched Membrane Vesicles. To test if differences in cytotoxicity were due at least in part to differences in ATP-dependent cellular efflux, DMA ${ }^{\mathrm{V}}$ transport by HEK- and HeLa-WT-MRP1 membrane vesicles was measured at 0.05 and $1 \mu \mathrm{M}$ of $\mathrm{DMA}^{\mathrm{V}}$ (Fig. 2A). MRP1-enriched vesicles prepared from transiently transfected HEK293T cells transported DMA ${ }^{\mathrm{V}}\left(101 \pm 15 \mathrm{pmol} \cdot \mathrm{mg}^{-1}\right.$ protein $\cdot \mathrm{min}^{-1}$ at $0.05 \mu \mathrm{M}$ and $264 \pm 42 \mathrm{pmol} \cdot \mathrm{mg}^{-1} \operatorname{protein} \cdot \mathrm{min}^{-1}$ at $1 \mu \mathrm{M})$. In contrast, DMA ${ }^{\mathrm{V}}$ transport was not detected for HeLa-WTMRP1 vesicles (Fig. 2A), despite the fact that the same vesicle preparations were functional for $\mathrm{MMA}(\mathrm{GS})_{2}$ transport (Fig. 4A), and
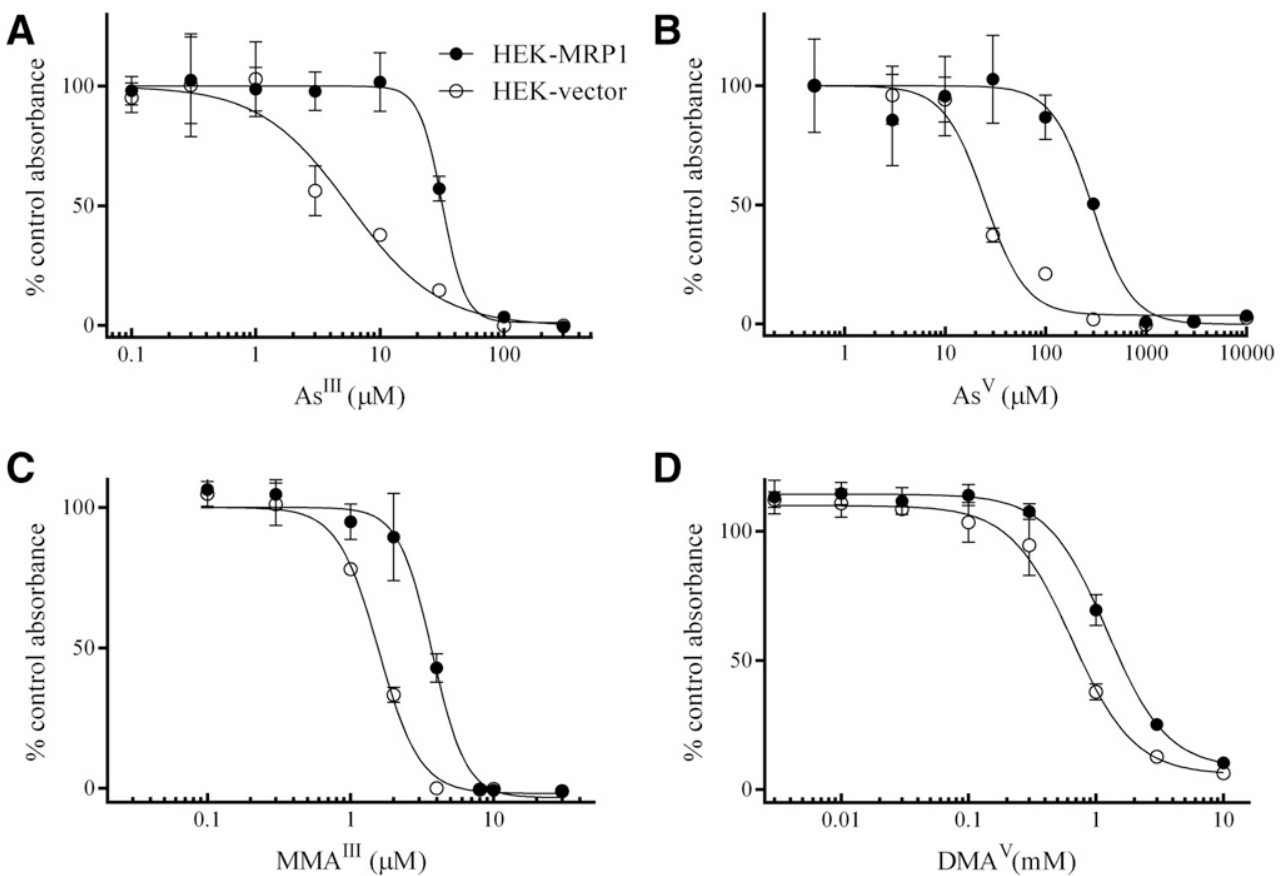

Fig. 1. Effect of selected arsenic compounds on the viability of HEK293 cells stably expressing human MRP1. Cells expressing empty vector (HEK-vector) (O) and MRP1 (HEK-MRP1) (৫) were incubated in the presence of $\mathrm{As}^{\mathrm{III}}(\mathrm{A})$, $\mathrm{As}^{\mathrm{V}}$ (B), MMA ${ }^{\mathrm{III}}$ (C), or DMA ${ }^{\mathrm{V}}$ (D) for 72 hours. Cell viability was determined using a tetrazolium-based cytotoxicity assay. Data points are means $( \pm$ S.D. $)$ of quadruplicate determinations in a representative experiment; similar results were obtained in at least two additional experiments (mean $\mathrm{IC}_{50}$ and relative resistance values from independent experiments are shown in Table 1). 
TABLE 1

Resistance of MRP1-transfected HEK293 and HeLa cells to inorganic and methylated arsenic species

\begin{tabular}{|c|c|c|c|c|c|c|}
\hline & \multicolumn{2}{|c|}{$\mathrm{IC}_{50}(\mu \mathrm{M})( \pm$ S.D. $)$} & \multirow{2}{*}{ Relative Resistance $^{a}$} & \multicolumn{2}{|c|}{$\mathrm{IC}_{50}(\mu \mathrm{M})( \pm$ S.D. $)$} & \multirow{2}{*}{ Relative Resistance ${ }^{c}$} \\
\hline & HEK-Vector & HEK-MRP1 & & HeLa-Vector & HeLa-MRP1 & \\
\hline $\mathrm{As}^{\mathrm{III}}$ & $4.9 \pm 1.0$ & $25.5 \pm 4.2$ & $5.3 \pm 0.9 * * * *$ & $7.0 \pm 1.2$ & $17.5 \pm 2.4$ & $2.5 \pm 0.3 * * *$ \\
\hline $\mathrm{As}^{\mathrm{V}}$ & $26 \pm 6.7$ & $221 \pm 62$ & $9.2 \pm 3.6^{* * *}$ & $156 \pm 55$ & $303 \pm 51$ & $2.1 \pm 0.5^{* *}$ \\
\hline MMA $^{\text {III }}$ & $1.7 \pm 0.12$ & $3.9 \pm 0.5$ & $2.3 \pm 0.2 * * *$ & $5.0 \pm 1.2$ & $7.6 \pm 1.3$ & $1.5 \pm 0.2^{*}$ \\
\hline $\mathrm{DMA}^{\mathrm{III}}$ & $1.2 \pm 1$ & $1.6 \pm 1.6$ & $1.2 \pm 0.2$ & $6 \pm 0.5^{b}$ & $7 \pm 2.3^{b}$ & $1.2 \pm 0.4^{b}$ \\
\hline $\mathrm{DMA}^{\mathrm{V}}$ & $1090 \pm 290$ & $1500 \pm 250$ & $1.4 \pm 0.2 *$ & $690 \pm 430$ & $680 \pm 450$ & $1.0 \pm 0.13$ \\
\hline
\end{tabular}

${ }^{a}$ Relative resistance factors were calculated by dividing the $\mathrm{IC}_{50}$ values obtained for the MRP1-expressing cell line by the $\mathrm{IC}_{50}$ values obtained for empty vector expressing cell line. Values shown are the mean ( \pm S.D.) obtained from at least three independent experiments. $\mathrm{IC}_{50}$ values for the MRP1 expressing cell lines were compared with the $\mathrm{IC}_{50}$ values for the empty vector control cell lines using a Student's $\mathrm{t}$ test $(* P<0.05, * * P<0.01, * * * P<0.001, * * * * P<0.0001)$

${ }^{b}$ Previously published in Carew et al. (2011) but done in parallel with HEK experiments.

comparable levels of MRP1 were present (Supplemental Fig. 1). For certain compounds transported by MRP1, GSH can either be required for or enhance transport (Cole, 2014). To determine whether this was the case for $\mathrm{DMA}^{\mathrm{V}}$, transport assays were completed in the presence of $3 \mathrm{mM} \mathrm{GSH}$ and this had no effect on HEK- or HeLa-WT-MRP1 $\mathrm{DMA}^{\mathrm{V}}$ transport activity (data not shown). Thus, we report for the first time that MRP1 is capable of transporting this important methylated arsenic metabolite, at least under certain conditions.

Kinetic Analysis of MRP1-Mediated DMA ${ }^{\mathbf{v}}$ Transport. Transport of DMA ${ }^{\mathrm{V}}$ by HEK-WT-MRP1 membrane vesicles was then further characterized. The linear range of $\mathrm{DMA}^{\mathrm{V}}(1 \mu \mathrm{M})$ transport versus time was measured for HEK-WT-MRP1 and HEK-vector control membrane vesicles (Fig. 2B). Transport by HEK-WT-MRP1 was linear for up to 30 seconds and reached a maximal activity of $138 \pm 24 \mathrm{pmol} \cdot \mathrm{mg}^{-1}$ protein at 30 seconds. ATP-dependent transport of DMA ${ }^{\mathrm{V}}$ by HEK-vector was very low and similar to transport observed in the presence of AMP. HEK-WT-MRP1 membrane vesicle transport of DMA ${ }^{\mathrm{V}}$ was characterized kinetically by determining the initial rates of transport over several concentrations of DMA ${ }^{\mathrm{V}}$ (Fig. 2C; Table 2). HEK-MRP1 was found to transport $\mathrm{DMA}^{\mathrm{V}}$ with high apparent affinity and capacity $\left(K_{\mathrm{m}}\right.$ of $0.19 \pm$ $0.06 \mu \mathrm{M}$ and $V_{\max }$ of $342 \pm 37 \mathrm{pmol} \cdot \mathrm{mg}^{-1}$ protein $\cdot \mathrm{min}^{-1}$ ).

Analysis of DMA ${ }^{\mathbf{v}}$ Transport by HEK-MRP1 Phosphorylation Mutants. Due to the complete lack of $\mathrm{DMA}^{\mathrm{V}}$ transport by HeLa-WTMRP1 and substantial transport by HEK-WT-MRP1 membrane vesicles, this cell line difference was further explored. We previously showed that HEK 293 and HeLa cell line differences in As(GS) 3 transport by MRP1 were associated with differences in phosphorylation at Y920/S921 (Shukalek et al., 2016). To determine if phosphorylation differences at these sites were responsible for the difference in $\mathrm{DMA}^{\mathrm{V}}$ transport by MRP1 between the two cell lines, DMA ${ }^{\mathrm{V}}$ transport by MRP1-Y920/S921 dephosphorylation- and phosphorylation-mimicking mutants was investigated.

Dephosphorylation-mimicking HEK-Y920F/S921A-MRP1 membrane vesicles exhibited a complete loss of DMA ${ }^{\mathrm{V}}$ transport (Fig. 3A), suggesting these sites are critical for the cell line difference. However, the phosphorylation-mimicking HEK-Y920E/S921E-MRP1, which we expected would restore $\mathrm{DMA}^{\mathrm{V}}$ transport, also completely lacked $\mathrm{DMA}^{\mathrm{V}}$ transport (Fig. 3A). Furthermore, individual dephosphorylation mimicking mutants Y920F-MRP1 and S921A-MRP1 also completely lost function (data not shown). Mutant membrane vesicle preparations had MRP1 levels similar to HEK-WT-MRP1 (Supplemental Fig. 1) and were functional

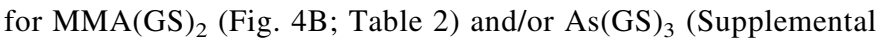
Fig. 2A) transport.

Analysis of DMA ${ }^{\mathrm{V}}$ Transport by HeLa-WT-MRP1 in the Presence of Phosphatase Inhibitors. The possible modulation of $\mathrm{DMA}^{\mathrm{V}}$ transport by MRP1 through phosphorylation was also investigated by studying the transport in MRP1-enriched vesicles prepared from HeLa cells in the presence or absence of a phosphatase inhibitor cocktail (PIC) at two different substrate concentrations $(0.05$ and $1 \mu \mathrm{M})$ (Fig. 3B). We previously showed for As(GS) $)_{3}$ that HeLa-WT-MRP1 membrane vesicles prepared in the presence of a PIC have a 19 - and 12-fold increase in $K_{\mathrm{m}}$ and $V_{\max }$, respectively, compared with HeLa-WT-MRP1 prepared in the absence of a PIC (Shukalek et al., 2016). In contrast, the inclusion of a PIC did not influence DMA ${ }^{\mathrm{V}}$ transport by HeLa-WT-MRP1 at either concentration (Fig. 3B). To ensure that the HeLa-WT-MRP1 \pm PIC membrane vesicles used in the $\mathrm{DMA}^{\mathrm{V}}$ transport assays were functional, and the PIC active, $\mathrm{As}(\mathrm{GS})_{3}$ transport experiments were completed on the same vesicle preparations (Fig. 3C). Consistent with our previous report (Shukalek et al., 2016), As(GS) ${ }_{3}$ transport by HeLa-WT-MRP1 vesicles, prepared in the presence of a PIC, was significantly higher than for HeLaWT-MRP1 vesicles prepared in the absence of a PIC. These results could suggest that mechanisms other than phosphorylation are likely responsible for the cell line difference observed in DMA ${ }^{\mathrm{V}}$ transport by HEK-WT-MRP1 compared with HeLa-WT-MRP1. Alternatively, a differential phosphorylation site that remains stable in the absence of PIC could be involved.

The lack of $\mathrm{DMA}^{\mathrm{V}}$ transport by all mutants of $\mathrm{Y} 920 / \mathrm{S} 921$ could also be due to the disruption of phosphorylation/dephosphorylation of neighboring sites that are critical for $\mathrm{DMA}^{\mathrm{V}}$ transport. We screened the influence of seven additional putative phosphorylation sites in the linker region (S905-, S915-, S916-, S917-, S918-, S919-, T931-MRP1) by mutating them to phospho-mimicking and/or dephospho-mimicking residues in full-length MRP1, expressing them in HEK293 cells, preparing membrane vesicles, and measuring $\mathrm{DMA}^{\mathrm{V}}$ transport. Surprisingly, all mutants lacked $\mathrm{DMA}^{\mathrm{V}}$ transport activity, despite the fact that they were comparable to HEK-WT-MRP1 for As(GS) $)_{3}$ transport and MRP1 level (Supplemental Fig. 2).

Inhibition of As(GS) $)_{3}$ Transport by DMA ${ }^{\mathbf{v}}$. To further characterize the differences in interaction of $\mathrm{As}(\mathrm{GS})_{3}$ and $\mathrm{DMA}^{\mathrm{V}}$ with MRP1, transport of $\mathrm{As}(\mathrm{GS})_{3}(1 \mu \mathrm{M})$ by HEK-WT-MRP1 vesicles was measured in the presence of $\mathrm{DMA}^{\mathrm{V}}$. DMA $^{\mathrm{V}}$ did not inhibit $\mathrm{As}(\mathrm{GS})_{3}$ transport even at a concentration of $1 \mathrm{mM}$ (data not shown), four orders of magnitude greater than the apparent $K_{\mathrm{m}}$ of DMA ${ }^{\mathrm{V}}$ for MRP1 (Table 2).

MRP1 Does Not Transport As ${ }^{\mathbf{V}}$. Given the striking difference in $\mathrm{As}^{\mathrm{V}}$ relative resistance levels between the HeLa and HEK293 cell line pairs [Fig. 1B; Table 1 and (Carew et al., 2011)], the ability of HEK-MRP1 and HeLa-MRP1 membrane vesicles to transport As ${ }^{\mathrm{V}}$ was investigated. As ${ }^{\mathrm{V}}$ (1 and $\left.10 \mu \mathrm{M}\right)$ was not transported by MRP1enriched membrane vesicles prepared from HEK293 cells in the presence or absence of $3 \mathrm{mM}$ GSH (data not shown). Similar results were obtained for membrane vesicles prepared from HeLa-MRP1 cells (data not shown). These results are consistent with a lack of detectable $\mathrm{As}^{\mathrm{V}}$ transport (in the presence and absence of GSH) by MRP1-enriched 


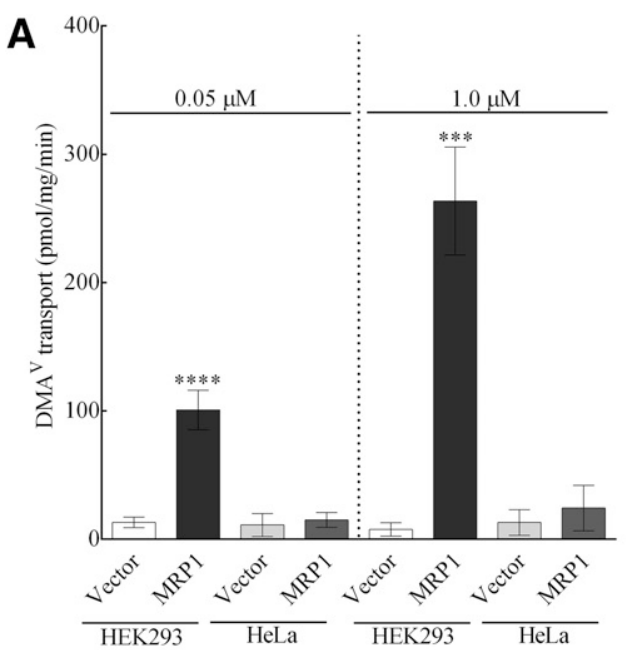

B

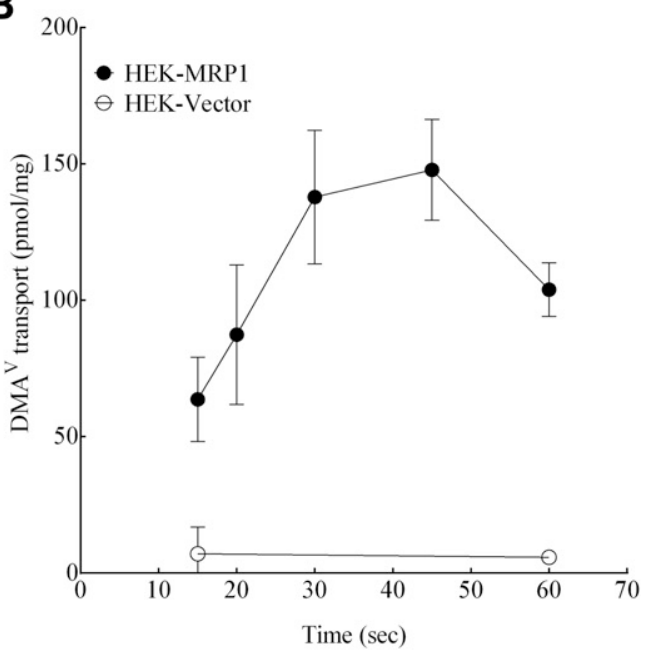

C

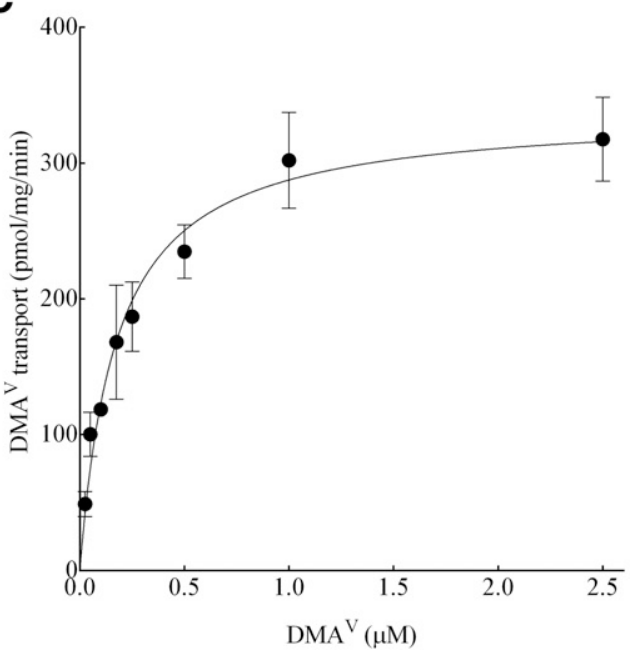

Fig. 2. ATP-dependent transport of $D M A^{\mathrm{V}}$ by MRP1-enriched membrane vesicles. Transport experiments were done with membrane vesicles (20 $\mu \mathrm{g}$ of protein) prepared from HEK293T cells transiently transfected with WT-MRP1 (black bars or symbols) or empty pcDNA3.1(-) (vector) (white bars or symbols) or HeLa cells stably transfected with WT-MRP1 (dark gray bars) or empty vector (light gray bars). For individual experiments, transport was done in triplicate, and then reactions were pooled for analysis by inductively coupled plasma mass spectrometry (ICP-MS). Bars and symbols represent the means ( \pm S.D.) of three independent experiments. (A) Vesicles were incubated for 20 seconds at $37^{\circ} \mathrm{C}$ in transport buffer with DMA $(0.05$ or $1 \mu \mathrm{M})$. Statistically significant differences in $\mathrm{DMA}^{\mathrm{V}}$ transport were determined using a one-way ANOVA followed by a Dunnett's multiple comparisons vesicles prepared from the H69AR small cell lung cancer cell line and our previous conclusion that inorganic arsenic ( $\mathrm{As}^{\mathrm{III}}$ and $\mathrm{As}^{\mathrm{V}}$ ) is metabolized to $\mathrm{As}(\mathrm{GS})_{3}$ before transport by MRP1 (Leslie et al., 2004).

Transport of MMA(GS) $)_{2}$ by MRP1-Enriched Membrane Vesicles. We previously showed that $\mathrm{MMA}^{\mathrm{III}}$ is transported by HEK-MRP1 in the form MMA(GS $)_{2}$ and that HeLa-MRP1 cells confer protection against MMA ${ }^{\mathrm{III}}$ relative to HeLa-vector cells (Carew et al., 2011). In the current study, HEK-MRP1 cells were also found to confer protection against MMA ${ }^{\mathrm{III}}$ relative to HEK-vector (Table 1). To determine if differences in transport characteristics existed between cell lines, MMA $(\mathrm{GS})_{2}$ transport by HEK- and HeLa-WT-MRP1-enriched vesicles was compared. Under the conditions tested, MMA(GS $)_{2}(1 \mu \mathrm{M})$ transport by HeLa-WT-MRP1 vesicles was 1.6-fold higher $(P<0.01)$ than HEK-WTMRP1 vesicles (Fig. 4A).

Kinetic Analysis of MRP1-Mediated MMA(GS $)_{2}$ Transport. To determine if the increased transport of $\mathrm{MMA}(\mathrm{GS})_{2}$ was due to changes in $K_{\mathrm{m}}$ and/or $V_{\max }$, MRP1-mediated transport of MMA(GS) was measured at an initial rate over eight different concentrations of MMA(GS) $)_{2}$ (Fig. 4B; Table 2). HEK- and HeLa-WT-MRP1 membrane vesicles were found to have similar apparent affinity for MMA(GS $)_{2}$ ( $K_{\mathrm{m}}$ of $23 \pm 2.2$ and $33 \pm 24 \mu \mathrm{M}$, respectively), similar to what we previously reported for HEK-WT-MRP1 (Carew et al., 2011). In contrast, the $V_{\max }$ was 3.4-fold higher for MMA(GS) $)_{2}$ transport by HeLa-WT-MRP1 $\left(V_{\max }\right.$ of $\left.17 \pm 5.3 \mathrm{nmol} \cdot \mathrm{mg}^{-1} \cdot \mathrm{min}^{-1}\right)$ than HEK-WT-MRP1 $\left(V_{\max }\right.$ of $\left.4.9 \pm 0.5 \mathrm{nmol} \cdot \mathrm{mg}^{-1} \cdot \mathrm{min}^{-1}\right)$ membrane vesicles (Fig. 4B; Table 2). In addition, kinetic characterization of $\operatorname{MMA}(\mathrm{GS})_{2}$ transport by the double dephosphorylation-mimicking mutant HEK-Y920F/S921A-MRP1 previously demonstrated to have substantially reduced apparent $K_{\mathrm{m}}$ and $V_{\max }$ values for As(GS) relative to HEK-WT-MRP1(Shukalek et al., 2016) was completed. Interestingly, HEK-Y920F/S921A-MRP1 had very similar apparent affinity $\left(K_{\mathrm{m}}\right.$ of $\left.24 \pm 5.5 \mu \mathrm{M}\right)$ and capacity $\left(V_{\max }\right.$ of $5.3 \pm$ $2.2 \mathrm{nmol} \cdot \mathrm{mg}^{-1} \cdot \mathrm{min}^{-1}$ ) to that of HEK-WT-MRP1 (Fig. 4B; Table 2). Consistent with this, the phosphorylation-mimicking mutant HEKY920E/S921E-MRP1 also had similar apparent affinity and capacity to HEK-WT-MRP1 (mean $K_{\mathrm{m}}$ of $24 \mu \mathrm{M}, V_{\max }$ of $5.5 \mathrm{nmol} \cdot \mathrm{mg}^{-1}$ protein $\cdot \min ^{-1}, n=2$ ) (Table 2). These data suggest that, in contrast with $\mathrm{As}(\mathrm{GS})_{3}$ transport, phosphorylation of Y920/S921 has little influence on the transport of MMA(GS $)_{2}$ by MRP1.

Inhibition of $\mathbf{A s}(\mathbf{G S})_{3}$ Transport by $\operatorname{MMA}(\mathbf{G S})_{2}$. Although the $K_{\mathrm{m}}$ of As(GS) $)_{3}$ for MRP1 was $>10$-fold higher for HEK-WT-MRP1 compared with HeLa-WT-MRP1 and HEK-Y920F/S921A-MRP1 (Shukalek et al., 2016), no difference between the apparent $K_{\mathrm{m}}$ value for MMA $(\mathrm{GS})_{2}$ transport was observed for these membrane vesicles (Fig. 4; Table 2). This result suggested that $\mathrm{MMA}(\mathrm{GS})_{2}$ and $\mathrm{As}(\mathrm{GS})_{3}$ interact at nonidentical binding sites. To begin to characterize the differences in interaction of $\mathrm{As}(\mathrm{GS})_{3}$ and $\mathrm{MMA}(\mathrm{GS})_{2}$ with MRP1, transport of $\mathrm{As}(\mathrm{GS})_{3}(1 \mu \mathrm{M})$ by HEK-WT-MRP1 vesicles was measured in the presence of increasing concentrations of $\mathrm{MMA}(\mathrm{GS})_{2}$ (Fig. 5A). $\mathrm{MMA}(\mathrm{GS})_{2}$ was found to potently inhibit $\mathrm{As}(\mathrm{GS})_{3}$ transport with an $\mathrm{IC}_{50}$ value of $11 \pm 1.5 \mu \mathrm{M}$.

The inhibition of $\mathrm{As}(\mathrm{GS})_{3}$ transport by $\mathrm{MMA}(\mathrm{GS})_{2}$ was further characterized by measuring the effect of $\operatorname{MMA}(\mathrm{GS})_{2}(5,10$, and $15 \mu \mathrm{M})$

post hoc test with HEK-Vector as the control group $(* * * P<0.001$; ****P $<$ 0.0001). (B) Time course of ATP-dependent DMA ${ }^{\mathrm{v}}$ transport was determined by incubating membrane vesicles with $\mathrm{DMA}^{\mathrm{V}}(1 \mu \mathrm{M})$ in transport buffer at $37^{\circ} \mathrm{C}$ for the indicated time points. (C) HEK-WT-MRP1 membrane vesicles were incubated for 20 seconds at $37^{\circ} \mathrm{C}$ with increasing concentrations of $\mathrm{DMA}^{\mathrm{V}}(0.025-2.5 \mu \mathrm{M})$. Data were fitted using a one-site Michaelis-Menten kinetic model with GraphPad Prism6. 
TABLE 2

Kinetic parameters of MMA(GS) $)_{2}$ and $\mathrm{DMA}^{\mathrm{V}}$ transport by MRP1 (and phosphorylation mutants)

\begin{tabular}{|c|c|c|c|c|c|}
\hline \multicolumn{6}{|c|}{ Kinetic parameter } \\
\hline Compound & Cell Line & Variant & $n$ & $K_{\mathrm{m}}(\mu \mathrm{M})$ & $V_{\max }^{a}$ \\
\hline $\mathrm{DMA}^{\mathrm{V}}$ & HEK293T & WT & 3 & $0.19 \pm 0.06$ & $342 \pm 37^{b}$ \\
\hline \multirow[t]{4}{*}{$\operatorname{MMA}(\mathrm{GS})_{2}$} & HEK293T & WT & 3 & $23 \pm 2.2$ & $4.9 \pm 0.5$ \\
\hline & & Y920F/S921A & 4 & $24 \pm 5.5$ & $5.3 \pm 2.2$ \\
\hline & & Y920E/S921E & 2 & 29,18 & $5.8,5.0$ \\
\hline & HeLa & WT & 3 & $33 \pm 24$ & $16.8 \pm 5.3^{* *}$ \\
\hline
\end{tabular}

${ }^{a} V_{\max }$ values are in $\mathrm{nmol} \mathrm{mg}{ }^{-1}$ protein $\min ^{-1}$ unless otherwise indicated and were corrected for MRP1-level relative to HEK-WT-MRP1 as described in Materials and Methods.

${ }^{b} \mathrm{pmol} \mathrm{mg}^{-1}$ protein $\mathrm{min}^{-1}$

**Significantly different from HEK293-MRP1 $(P<0.01$; one-way ANOVA with Tukey's multiple comparisons post hoc test).

on $\mathrm{As}(\mathrm{GS})_{3}(0.1-20 \mu \mathrm{M})$ transport $(15 \mu \mathrm{M}$ shown in Fig. 5B). Michaelis-Menten analysis showed that MMA $(\mathrm{GS})_{2}$ at each concentration tested reduced both the apparent $K_{\mathrm{m}}$ and $V_{\max }$ values, suggesting an uncompetitive mode of inhibition with an average $K_{\mathrm{i}}$ of $7.3 \pm 5.1 \mu \mathrm{M}$ $( \pm \text { S.D., } n=3 \text { ). These data are consistent with MMA(GS })_{2}$ and $\mathrm{As}(\mathrm{GS})_{3}$ interacting at nonidentical binding sites.

\section{Discussion}

The proven human carcinogen arsenic naturally contaminates the drinking water of hundreds of millions of people worldwide. One of the most affected countries is Bangladesh, where the arsenic contamination has been referred to as "the largest mass poisoning of a population in history" (Smith et al., 2000). Understanding the cellular handling of arsenic, including efflux pathways, is critical for the prevention and treatment of arsenic-induced disease.

We investigated the ability of MRP1 to confer resistance to and/or transport important methylated arsenic metabolites when expressed in HEK293 cells compared with HeLa cells. The cellular resistance conferred by MRP1 against different arsenic species is useful information; however, resistance levels can be influenced by cellular metabolism and uptake efficiency. To draw conclusions about MRP1-mediated transport of specific arsenic compounds, it was critical to measure their transport directly using MRP1enriched membrane vesicles. The population of membrane vesicles that is accumulating MRP1 substrates are inside-out, allowing the measurement of ATP-dependent transport with minimal influence of metabolism and cellular uptake. This allows the MRP1 contribution to cellular export of specific arsenic compounds to be evaluated and allows the accurate determination of kinetic parameters.

The most pronounced difference between cell lines was for $\mathrm{DMA}^{\mathrm{V}}$, which HEK-MRP1 cells conferred resistance to and HEK-WT-MRP1 membrane vesicles transported with high apparent affinity and capacity (Fig. 2; Table 1). This is the first report that MRP1 is capable of transporting this important arsenic metabolite. In contrast, HeLa-MRP1 cells did not confer resistance to $\mathrm{DMA}^{\mathrm{V}}$ relative to HeLa-vector cells (Carew et al., 2011), and HeLa-WT-MRP1 membrane vesicles did not have detectable $\mathrm{DMA}^{\mathrm{V}}$ transport activity (Fig. 2A).

The relative resistance conferred by MRP1 expressed in HEK293 cells was small, but significant (1.4-fold, $P<0.05$, Fig. 1C; Table 1). This marginal resistance was in contrast with the high-affinity and highcapacity transport of DMA ${ }^{\mathrm{V}}$ observed with HEK-WT-MRP1-enriched membrane vesicles (Fig. 2C; Table 2). A likely explanation for the

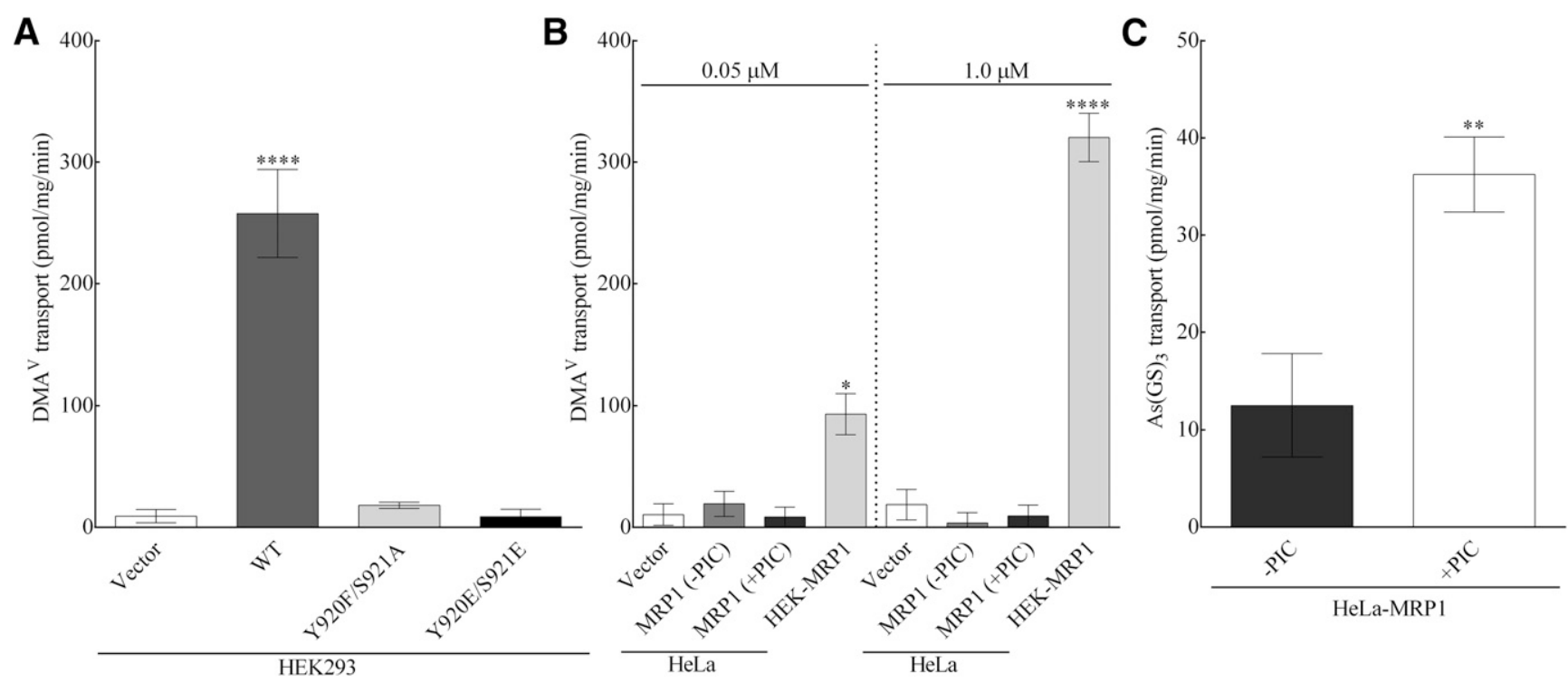

Fig. 3. Effect of Y920/S921-MRP1 mutation and/or phosphatase inhibitors on ATP-dependent transport of DMA ${ }^{\mathrm{V}}$ or As(GS) 3 by MRP1-enriched membrane vesicles. Transport experiments were done with membrane vesicles (20 $\mu \mathrm{g}$ of protein) prepared from HEK293T cells transiently transfected with WT-MRP1, Y920F/S921A-MRP1, Y920E/S921E-MRP1, or empty pcDNA3.1(-) (vector) or from HeLa cells stably transfected with WT-MRP1 or empty vector. Bars and symbols represent the means ( \pm S. D.) of three independent experiments. (A) Membrane vesicles from HEK293T cells transiently transfected with WT-MRP1 (dark gray bars), Y920F/S921A-MRP1 (light gray bars), Y920E/S921E-MRP1 (black bars), or vector (white bars) were incubated for 20 seconds at $37^{\circ} \mathrm{C}$ with $\mathrm{DMA}^{\mathrm{V}}(1 \mu \mathrm{M})$. For individual experiments, transport was done in triplicate, and then reactions were pooled for analysis by ICP-MS. Statistically significant differences in DMA ${ }^{\mathrm{v}}$ transport were determined using a one-way ANOVA followed by a Dunnett's multiple comparisons post hoc test using HEK-Vector as the control group (**** $P<0.0001)$. (B) Membrane vesicles from HeLa cells stably transfected with vector (light gray bars) or WT-MRP1 prepared in the presence (white bars) or absence (black bars) of a PIC were incubated for 20 seconds at $37^{\circ} \mathrm{C}$ with DMA $^{\mathrm{V}}(0.05$ or $1 \mu \mathrm{M})$. HEK-WT-MRP1 membrane vesicles were used as a positive control. For individual experiments, transport was done in triplicate, and then reactions were pooled for analysis by ICP-MS. Statistically significant differences in DMA ${ }^{\mathrm{v}}$ transport were determined using a one-way ANOVA followed by a Dunnett's multiple comparisons post hoc test using HeLa-Vector as the control group $(* P<0.05$; $* * * * P<0.0001)$. (C) ATP-dependent transport of As(GS) $)_{3}$ by MRP1-enriched membrane vesicles from stably transfected HeLa cells prepared with (white bar) or without (black bar) PIC. The membrane vesicles were incubated for 3 minutes at $37^{\circ} \mathrm{C}$ with $\mathrm{As}(\mathrm{GS})_{3}$ $(1 \mu \mathrm{M})$. Statistically significant differences in $\mathrm{As}(\mathrm{GS})_{3}$ transport were determined using an unpaired two-tailed $t$ test $(* * P<0.01)$. 

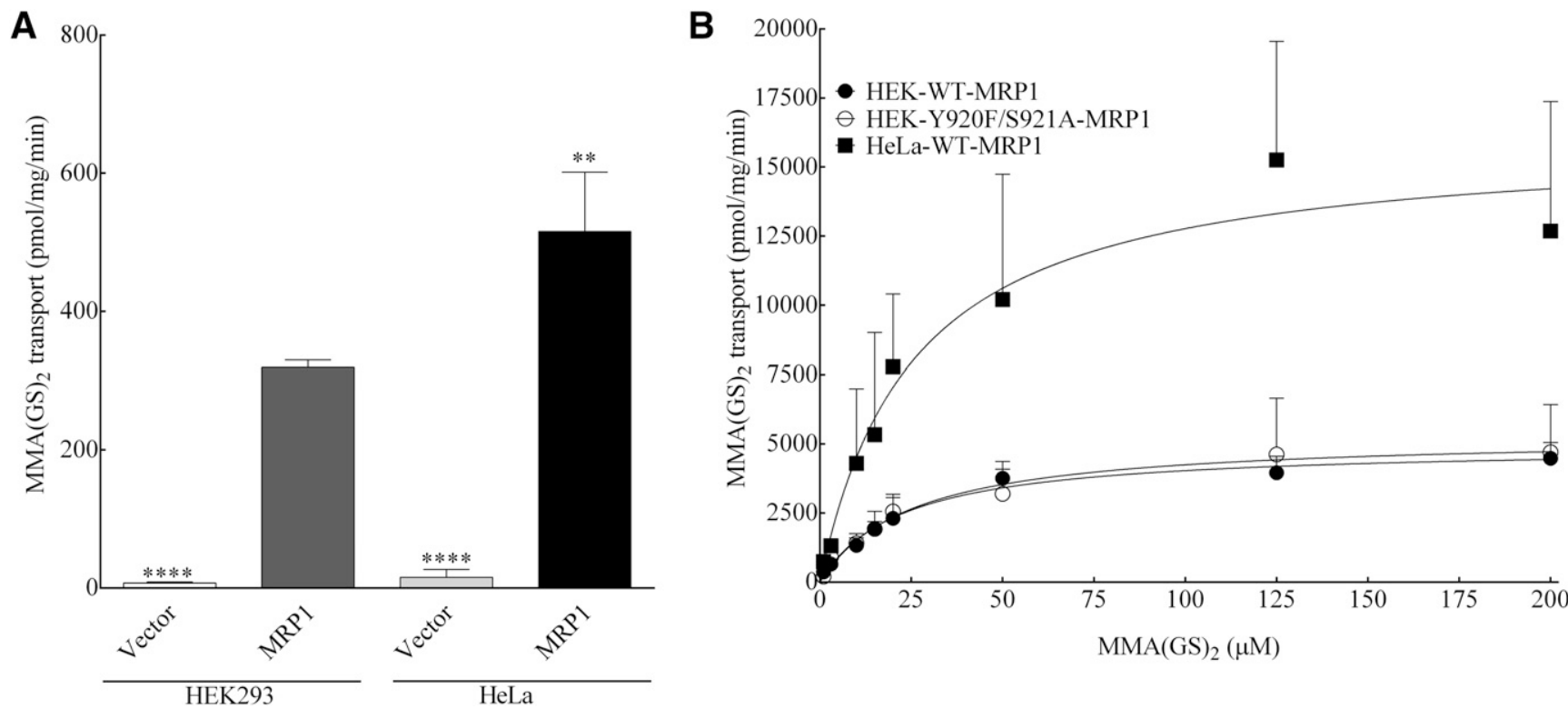

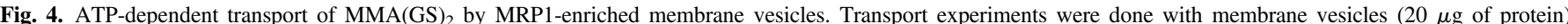

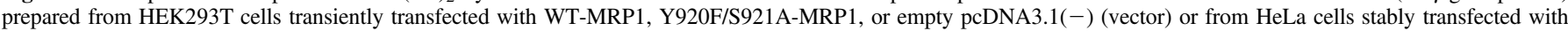

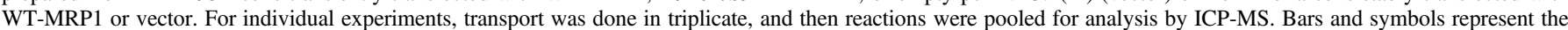

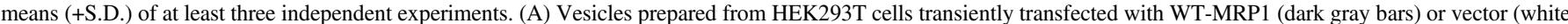

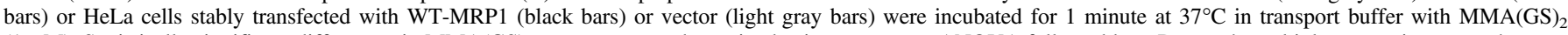

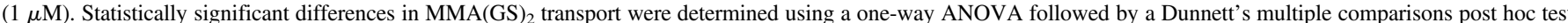

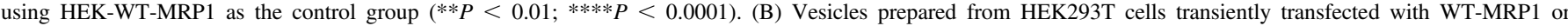

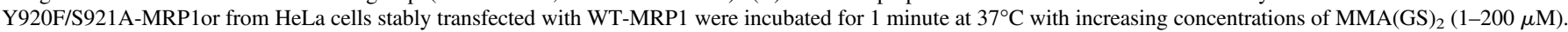
Data were fitted using a one-site Michaelis-Menten kinetic model with GraphPad Prism6.

difference in results between the two assays is that $\mathrm{DMA}^{\mathrm{V}}$ is poorly taken up by cells (Delnomdedieu et al., 1995; Dopp et al., 2004, 2005; Naranmandura et al., 2007, 2011), including HEK293 cells (Banerjee et al., 2014). Thus, it is likely that the data generated with the inside-out MRP1-enriched membrane vesicles, with no requirement for cell entry, more accurately reflects what is occurring after formation of DMA $\mathrm{V}$ within the cell. Humans are predominantly exposed to $\mathrm{As}^{\mathrm{III}}$ and $\mathrm{As}^{\mathrm{V}}$ in drinking water, which are taken up by cells efficiently (Roggenbeck et al., 2016) and then converted to methylated products (e.g., DMA ${ }^{\mathrm{V}}$ ).

As a starting point for determining a mechanism for cell line differences in MRP1-mediated DMA ${ }^{\mathrm{V}}$ transport, we investigated the potential contribution of differential phosphorylation. Mutation of two phosphorylation sites (Y920/S921-MRP1), previously reported as responsible for cell line differences in the transport of $\mathrm{As}(\mathrm{GS})_{3}$, to both phospho- or dephospho-mimicking amino acids, surprisingly resulted in a complete loss of DMA ${ }^{\mathrm{V}}$ transport. Individual mutant HEK-Y920FMRP1 and HEK-S921A-MRP1 membrane vesicles, shown previously to transport $\mathrm{As}(\mathrm{GS})_{3}$ to a similar extent as HEK-WT-MRP1, also completely lacked $\mathrm{DMA}^{\mathrm{V}}$ transport. The inclusion of a PIC during the preparation of HeLa-WT-MRP1 membrane vesicles did not result in a gain of $\mathrm{DMA}^{\mathrm{V}}$ transport activity (although MRP1-mediated As(GS) transport was increased), suggesting that either phosphorylation was not important or a stable phosphorylation site (not influenced by the PIC) was involved. Mutation of multiple other putative phosphorylation sites in the linker region also resulted in a complete loss of HEK-MRP1 $\mathrm{DMA}^{\mathrm{V}}$ transport. Our data suggest that $\mathrm{DMA}^{\mathrm{V}}$ transport by HEK-WTMRP1 membrane vesicles is extremely sensitive to alterations in the linker region between NBD1 and MSD2. The reasons for this are currently not understood and require further investigation. Differences in posttranslational modifications and/or protein:protein interactions that alter the structure of this region could potentially explain the cell line differences in MRP1-mediated DMA ${ }^{\mathrm{V}}$ transport. Indeed, there is some suggestion in the literature that this linker region is important for protein: protein interactions and that such interactions may be modulated by phosphorylation (Yang et al., 2012; Ambadipudi and Georges, 2017).

MRP1 transport of DMA ${ }^{\mathrm{V}}$ is the second $\mathrm{DMA}^{\mathrm{V}}$ efflux pathway to be identified. Previously, we reported that the related MRP4 transports DMA $^{\mathrm{V}}$ with similar affinity $\left(K_{0.5} 0.22 \pm 0.15 \mu \mathrm{M}\right.$ for MRP4 vs. $K_{\mathrm{m}}$ $0.19 \pm 0.06 \mu \mathrm{M}$ for MRP1), but through a cooperative mechanism (Hill coefficient $2.9 \pm 1.2$ ) and assuming equal protein levels, lower capacity $\left(V_{\max } 32 \pm 3 \mathrm{pmol} \cdot \mathrm{mg}^{-1}\right.$ protein $\cdot \min ^{-1}$ for MRP4 vs. $V_{\max }$ $342 \pm 37 \mathrm{pmol} \cdot \mathrm{mg}^{-1}$ protein $\cdot \mathrm{min}^{-1}$ for MRP1) [(Banerjee et al., 2014, 2016) and Table 2]. The tissue expression and cellular localization of MRP4 likely make it critical for urinary elimination of hepatic metabolites (Banerjee et al., 2014). The localization of MRP1 to the basolateral surface of epithelial cells and expression in specific cell types of most tissues (undetectable protein levels in human hepatocytes), likely makes MRP1 important for cellular/tissue protection rather than playing a role in arsenic elimination.

$\mathrm{DMA}^{\mathrm{v}}$ is an arsenic compound with low toxicity relative to trivalent arsenic species (Moe et al., 2016). The efflux of $\mathrm{DMA}^{\mathrm{V}}$ from the cell is critical to prevent the reduction of $\mathrm{DMA}^{\mathrm{V}}$ to the highly reactive $\mathrm{DMA}^{\mathrm{III}}$ (Nemeti and Gregus, 2013). Furthermore, export of DMA ${ }^{\mathrm{V}}$ would likely prevent product inhibition of arsenic ( +3 oxidation state) methyltransferase, allowing the formation and cellular export of more DMA ${ }^{\mathrm{V}}$. The reducing intracellular environment might suggest that $\mathrm{DMA}^{\mathrm{III}}$ is the predominant form of dimethylated arsenic within the cell; however, this has been difficult to prove and $\mathrm{DMA}^{\mathrm{V}}$ has been detected in human cell lines and mouse liver homogenate (Currier et al., 2011). The highly reactive $\mathrm{DMA}^{\mathrm{III}}$ is highly protein bound and unlikely to be available for cellular export (Hippler et al., 2011; Shen et al., 2013). An equilibrium between $\mathrm{DMA}^{\mathrm{III}}$ and $\mathrm{DMA}^{\mathrm{V}}$ will exist within the cell, and the highaffinity high-capacity export of $\mathrm{DMA}^{\mathrm{V}}$ by MRP1 would provide a good mechanism for cellular detoxification. 

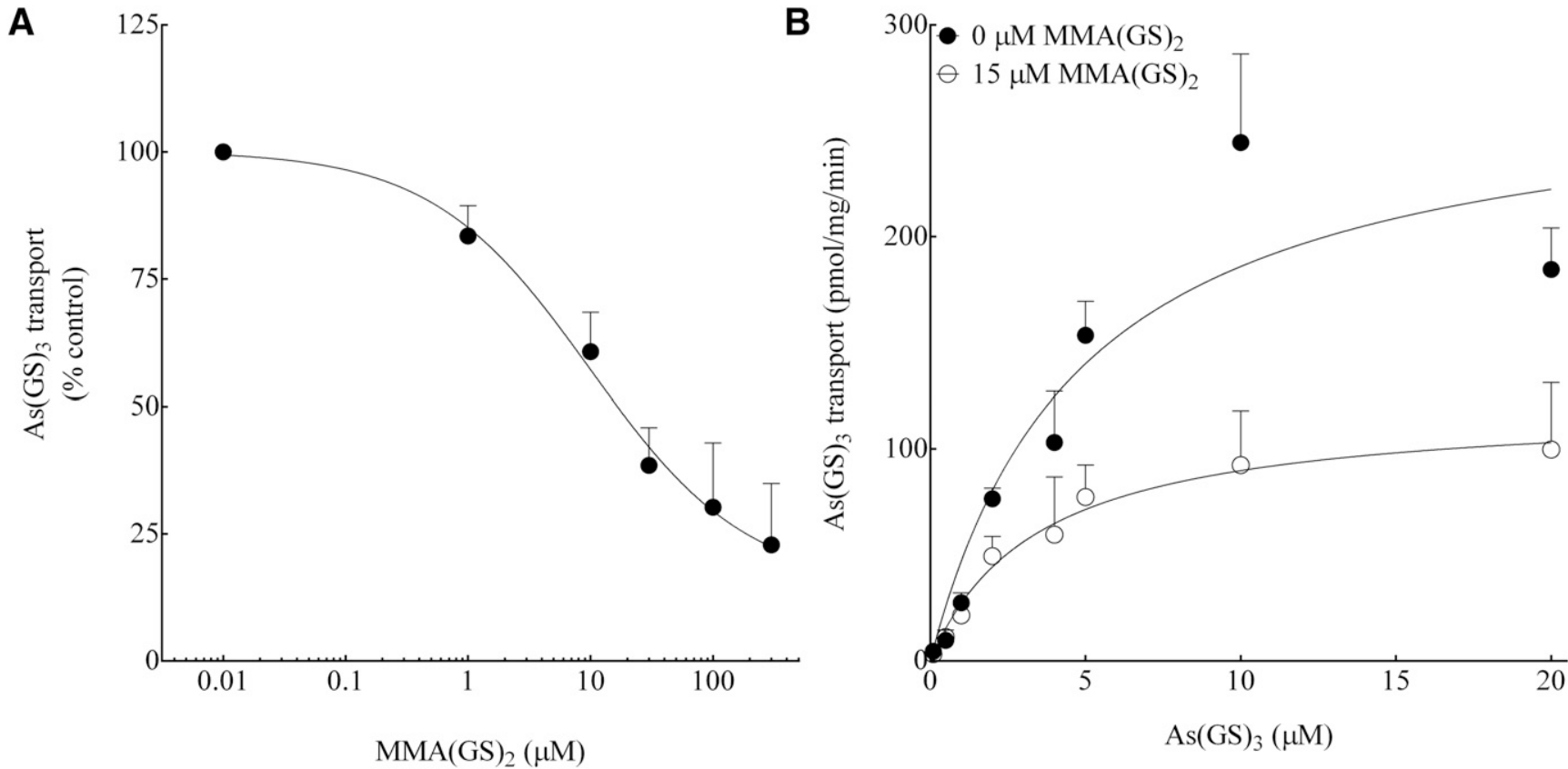

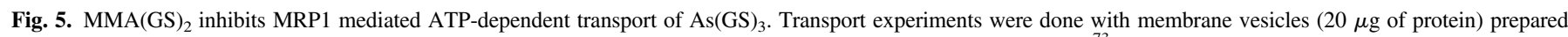

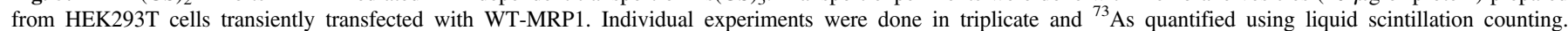

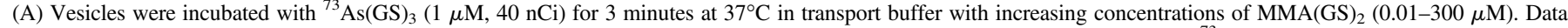

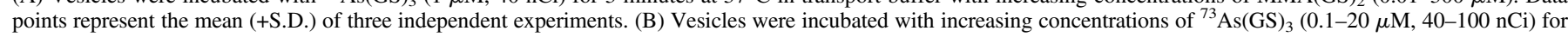

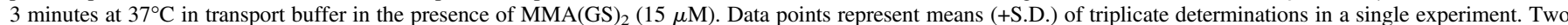
independent additional experiments with $\mathrm{MMA}(\mathrm{GS})_{2}$ at 5 and $10 \mu \mathrm{M}$ were done to calculate the $K_{\mathrm{i}}(7.3 \pm 5.1 \mu \mathrm{M}, \pm \mathrm{S} . \mathrm{D}$., $n=3)$.

Out of the five arsenic compounds tested HEK-MRP1 conferred the highest level of resistance against $\mathrm{As}^{\mathrm{V}}$ (9-fold) followed by $\mathrm{As}^{\mathrm{III}}$ (5fold). Consistent with previous studies using MRP1-enriched membrane vesicles isolated from H69AR cells (Leslie et al., 2004), HEK- and HeLa MRP1-enriched vesicles did not transport $\mathrm{As}^{\mathrm{V}}$ in the presence or absence of GSH. Once inside the cell, $\mathrm{As}^{\mathrm{V}}$ is reduced to $\mathrm{As}{ }^{\mathrm{III}}$ and then enters the methylation pathway (Cullen, 2014). Thus, our results are consistent with $\mathrm{As}^{\mathrm{V}}$ and $\mathrm{As}{ }^{\mathrm{III}}$ being converted to $\mathrm{As}(\mathrm{GS})_{3}$ before efflux by MRP1, as we showed previously (Leslie et al., 2004). The reason why HEK-MRP1 cells confer higher levels of resistance to $\mathrm{As}^{\mathrm{V}}$ than $\mathrm{As}{ }^{\mathrm{III}}$ is not understood. As ${ }^{\mathrm{V}}$ enters cells more slowly (through $\mathrm{Na}^{+}$-dependent phosphate transporters) than As ${ }^{\text {III }}$ (through aquaglyceroporins) (Mukhopadhyay et al., 2014; Roggenbeck et al., 2016), and this could influence the methylation and glutathionylation of arsenic and alter the metabolites available for MRP1 export.

HEK-MRP1 and HeLa-MRP1 cell lines both conferred significantly higher levels of resistance to $\mathrm{MMA}^{\mathrm{III}}$ than their respective vector controls [(Carew et al., 2011) and Table 1]. MMA(GS $)_{2}$ was transported with comparable apparent affinity by HeLa-WT-MRP1 and HEK-WT-MRP1 membrane vesicles; however, the $V_{\max }$ was 3.4-fold higher for HeLa-MRP1 membrane vesicles. Kinetic parameters for $\mathrm{MMA}(\mathrm{GS})_{2}$ transport were not significantly different between HEK-WT-MRP1 and HEKY920F/S921A-MRP1 or HEK-Y920E/S921E-MRP1, suggesting that differential phosphorylation at these sites is not responsible for the cell line differences in $V_{\max }$. Consistent with these phosphorylation sites being important for the interaction between MRP1 and $\mathrm{As}(\mathrm{GS})_{3}$, but not MRP1 and $\mathrm{MMA}(\mathrm{GS})_{2}$, we found that $\mathrm{MMA}(\mathrm{GS})_{2}$ was an uncompetitive inhibitor of $\mathrm{As}(\mathrm{GS})_{3}$ transport. Thus, increasing concentrations of $\mathrm{As}(\mathrm{GS})_{3}$ did not overcome MMA(GS) $)_{2}$ inhibition (Fig. $5 \mathrm{~B}$ ), providing support for the idea that $\mathrm{As}(\mathrm{GS})_{3}$ and MMA $(\mathrm{GS})_{2}$ do not share identical binding sites.

Arsenic was previously reported to activate kinase and inhibit phosphatase pathways (Rehman et al., 2012; Beauchamp et al., 2015), and we had postulated cellular exposure to arsenic would result in a shift to a prophosphorylation state of Y920/S921-MRP1 (Shukalek et al., 2016). This in turn would result in the switch of MRP1 from a high-affinity, low-capacity transporter of $\mathrm{As}(\mathrm{GS})_{3}$ to a more efficient low-affinity, high-capacity As(GS) $)_{3}$ transporter (Shukalek et al., 2016). Phosphorylation of these residues appear to be important specifically for $\mathrm{As}(\mathrm{GS})_{3}$, but not for MMA $(\mathrm{GS})_{2}$ or DMA ${ }^{\mathrm{V}}$ (this study) or as previously reported for methotrexate, leukotriene $\mathrm{C} 4$, or $17 \beta$-estradiol $17-(\beta$-Dglucuronide) (Loe et al., 1996b; Stride et al., 1997; Shukalek et al., 2016). Why phosphorylation of MRP1 at Y920/S921 has an impact on $\mathrm{As}(\mathrm{GS})_{3}$, but not other arsenic metabolites is unknown. Potentially, MRP1 exports As $(\mathrm{GS})_{3}$ over a broad concentration range to reduce As ${ }^{\text {III }}$ availability for the formation of more toxic trivalent methylated forms. The $K_{\mathrm{m}}$ values for $\mathrm{As}(\mathrm{GS})_{3}\left(K_{\mathrm{m}}\right.$ range $\left.\sim 0.3-4 \mu \mathrm{M}\right)$ (Leslie et al., 2004; Shukalek et al., 2016) and $\mathrm{DMA}^{\mathrm{V}}\left(K_{\mathrm{m}} 0.19 \mu \mathrm{M}\right)$ (Table 2) are much lower than MMA $(\mathrm{GS})_{2}\left(K_{\mathrm{m}}\right.$ range $\left.11-33 \mu \mathrm{M}\right)$ [Table 2 and (Carew et al., 2011)]. At low levels of arsenic exposure, MRP1 is potentially important for the export of $\mathrm{As}(\mathrm{GS})_{3}$, and any $\mathrm{DMA}^{\mathrm{V}}$ that is formed (preventing the formation of the highly toxic DMA ${ }^{\mathrm{III}}$ ). During higher cellular arsenic exposure, MRP1 phosphorylation allows it to still export $\mathrm{As}(\mathrm{GS})_{3}$ efficiently; $\mathrm{MMA}(\mathrm{GS})_{2}$ accumulation might start to occur and MRP1 would be able to export this, and potentially $\mathrm{DMA}^{\mathrm{V}}$. It is worth noting that the transport of $\mathrm{DMA}^{\mathrm{V}}$ by MRP1 is remarkably more efficient than reported for any other transporter and arsenical combination (Roggenbeck et al., 2016), providing support for MRP1 being an important transport pathway for $\mathrm{DMA}^{\mathrm{V}}$ under environmentally relevant exposure conditions.

Differences in MRP1 transport of DMA ${ }^{\mathrm{V}}$ (this study) and $\mathrm{As}(\mathrm{GS})_{3}$ (Shukalek et al., 2016) by membrane vesicles isolated from different cells raises the possibility that MRP1 could have a distinct role in arsenic efflux, depending in which tissue and/or cell type it is expressed. MRP1 has been indirectly implicated in the protection of specific tissues from 
arsenic toxicity, including kidney and brain (Kimura et al., 2005, 2006; Dringen et al., 2016; Wang et al., 2016). Furthermore, MRP1 could play a role in resistance to arsenic-based therapies and this could be modified depending upon the tumor type. This study lays the groundwork for further investigation into how the cellular environment influences the function of MRP1, particularly for the cellular detoxification of important arsenic metabolites.

\section{Acknowledgments}

Diane Swanlund is thanked for outstanding technical assistance. Xiufen $\mathrm{Lu}$ is gratefully acknowledged for assistance with inductively coupled plasma mass spectrometry. Dr. Susan P.C. Cole (Queen's University) is thanked for providing the HEK/HeLa-MRP1 and HeLa-vector stable cell lines and the pcDNA3.1(-) MRP1. The 73-arsenic used in this research was supplied by the United States Department of Energy Office of Science by the Isotope Program in the Office of Nuclear Physics.

\section{Authorship Contributions}

Participated in research design: Banerjee, Kaur, Whitlock, Carew, Le, Leslie.

Conducted experiments: Banerjee, Kaur, Whitlock, Carew.

Contributed new reagents or analytic tools: Le.

Performed data analysis: Banerjee, Kaur, Whitlock, Carew, Leslie.

Wrote or contributed to the writing of the manuscript: Banerjee, Kaur, Whitlock, Leslie.

\section{References}

Ally MS, Ransohoff K, Sarin K, Atwood SX, Rezaee M, Bailey-Healy I, Kim J, Beachy PA, Chang AL, Oro A, et al. (2016) Effects of combined treatment with arsenic trioxide and itraconazole in patients with refractory metastatic basal cell carcinoma. JAMA Dermatol 152:452-456.

Ambadipudi R and Georges E (2017) Sequences in Linker-1 domain of the multidrug resistance associated protein (MRP1 or ABCC1) bind to tubulin and their binding is modulated by phosphorylation. Biochem Biophys Res Commun 482:1001-1006.

Banerjee M, Carew MW, Roggenbeck BA, Whitlock BD, Naranmandura H, Le XC, and Leslie EM (2014) A novel pathway for arsenic elimination: human multidrug resistance protein 4 (MRP4/ABCC4) mediates cellular export of dimethylarsinic acid (DMAV) and the diglutathione conjugate of monomethylarsonous acid (MMAIII). Mol Pharmacol 86:168-179.

Banerjee M, Marensi V, Conseil G, Le XC, Cole SP, and Leslie EM (2016) Polymorphic variants of MRP4/ABCC4 differentially modulate the transport of methylated arsenic metabolites and physiological organic anions. Biochem Pharmacol 120:72-82.

Beauchamp EM, Kosciuczuk EM, Serrano R, Nanavati D, Swindell EP, Viollet B, O'Halloran TV, Altman JK, and Platanias LC (2015) Direct binding of arsenic trioxide to AMPK and generation of inhibitory effects on acute myeloid leukemia precursors. Mol Cancer Ther 14:202-212.

Bu N, Wang HY, Hao WH, Liu X, Xu S, Wu B, Anan Y, Ogra Y, Lou YJ, and Naranmandura H (2011) Generation of thioarsenicals is dependent on the enterohepatic circulation in rats. Metallomics 3:1064-1073.

Carew MW and Leslie EM (2010) Selenium-dependent and -independent transport of arsenic by the human multidrug resistance protein 2 (MRP2/ABCC2): implications for the mutual detoxification of arsenic and selenium. Carcinogenesis 31:1450-1455.

Carew MW, Naranmandura H, Shukalek CB, Le XC, and Leslie EM (2011) Monomethylarsenic diglutathione transport by the human multidrug resistance protein 1 (MRP1/ABCC1). Drug Metab Dispos 39:2298-2304.

Cicconi L and Lo-Coco F (2016) Current management of newly diagnosed acute promyelocytic leukemia. Ann Oncol 27:1474-1481.

Cole SP (2014) Multidrug resistance protein 1 (MRP1, ABCC1), a "multitasking" ATP-binding cassette (ABC) transporter. J Biol Chem 289:30880-30888.

Cole SP and Deeley RG (2006) Transport of glutathione and glutathione conjugates by MRP1. Trends Pharmacol Sci 27:438-446.

Conseil G and Cole SP (2013) Two polymorphic variants of ABCC1 selectively alter drug resistance and inhibitor sensitivity of the multidrug and organic anion transporter multidrug resistance protein 1. Drug Metab Dispos 41:2187-2196.

Cui X, Kobayashi Y, Hayakawa T, and Hirano S (2004) Arsenic speciation in bile and urine following oral and intravenous exposure to inorganic and organic arsenics in rats. Toxicol Sci $\mathbf{8 2}$ 478-487.

Cullen WR (2014) Chemical mechanism of arsenic biomethylation. Chem Res Toxicol 27:457-461. Cullen WR, Liu Q, Lu X, McKnight-Whitford A, Peng H, Popowich A, Yan X, Zhang Q, Fricke M, Sun H, et al. (2016) Methylated and thiolated arsenic species for environmental and health research - a review on synthesis and characterization. J Environ Sci (China) 49:7-27.

Currier JM, Svoboda M, de Moraes DP, Matousek T, Dědina J, and Stýblo M (2011) Direct analysis of methylated trivalent arsenicals in mouse liver by hydride generation-cryotrappingatomic absorption spectrometry. Chem Res Toxicol 24:478-480.

Delnomdedieu M, Styblo M, and Thomas DJ (1995) Time dependence of accumulation and binding of inorganic and organic arsenic species in rabbit erythrocytes. Chem Biol Interact 98:69-83.

Dopp E, Hartmann LM, Florea AM, von Recklinghausen U, Pieper R, Shokouhi B, Rettenmeier AW, Hirner AV, and Obe G (2004) Uptake of inorganic and organic derivatives of arsenic associated with induced cytotoxic and genotoxic effects in Chinese hamster ovary (CHO) cells. Toxicol Appl Pharmacol 201:156-165.
Dopp E, Hartmann LM, von Recklinghausen U, Florea AM, Rabieh S, Zimmermann U, Shokouhi B, Yadav S, Hirner AV, and Rettenmeier AW (2005) Forced uptake of trivalent and pentavalent methylated and inorganic arsenic and its cyto-/genotoxicity in fibroblasts and hepatoma cells. Toxicol Sci 87:46-56.

Dringen R, Spiller S, Neumann S, and Koehler Y (2016) Uptake, metabolic effects and toxicity of arsenate and arsenite in astrocytes. Neurochem Res 41:465-475.

Drobna Z, Naranmandura H, Kubachka KM, Edwards BC, Herbin-Davis K, Styblo M, Le XC, Creed JT, Maeda N, Hughes MF, et al. (2009) Disruption of the arsenic ( +3 oxidation state) methyltransferase gene in the mouse alters the phenotype for methylation of arsenic and affects distribution and retention of orally administered arsenate. Chem Res Toxicol $\mathbf{2 2}$ $1713-1720$.

Drobná Z, Walton FS, Harmon AW, Thomas DJ, and Stýblo M (2010) Interspecies differences in metabolism of arsenic by cultured primary hepatocytes. Toxicol Appl Pharmacol 245:47-56.

Falchi L, Verstovsek S, Ravandi-Kashani F, and Kantarjian HM (2016) The evolution of arsenic in the treatment of acute promyelocytic leukemia and other myeloid neoplasms: moving toward an effective oral, outpatient therapy. Cancer 122:1160-1168

Hipfner DR, Gauldie SD, Deeley RG, and Cole SP (1994) Detection of the M(r) 190,000 multidrug resistance protein, MRP, with monoclonal antibodies. Cancer Res 54:5788-5792.

Hippler J, Zdrenka R, Reichel RAD, Weber DG, Rozynek P, Johnen G, Dopp E, and Hirnera AV (2011) Intracellular, time-resolved speciation and quantification of arsenic compounds in human urothelial and hepatoma cells. J Anal At Spectrom 26:2396-2403.

Hughes MF, Edwards BC, Herbin-Davis KM, Saunders J, Styblo M, and Thomas DJ (2010) Arsenic ( +3 oxidation state) methyltransferase genotype affects steady-state distribution and clearance of arsenic in arsenate-treated mice. Toxicol Appl Pharmacol 249:217-223.

IARC (International Agency for Research on Cancer) (2012) Arsenic, metals, fibres, and dusts. IARC Monogr Eval Carcinog Risks Hum 100:11-465.

Ito K, Olsen SL, Qiu W, Deeley RG, and Cole SP (2001) Mutation of a single conserved tryptophan in multidrug resistance protein 1 (MRP1/ABCC1) results in loss of drug resistance and selective loss of organic anion transport. J Biol Chem 276:15616-15624.

Jedlitschky G, Leier I, Buchholz U, Barnouin K, Kurz G, and Keppler D (1996) Transport of glutathione, glucuronate, and sulfate conjugates by the MRP gene-encoded conjugate export pump. Cancer Res 56:988-994.

Kala SV, Kala G, Prater CI, Sartorelli AC, and Lieberman MW (2004) Formation and urinary excretion of arsenic triglutathione and methylarsenic diglutathione. Chem Res Toxicol 17.243-249.

Kala SV, Neely MW, Kala G, Prater CI, Atwood DW, Rice JS, and Lieberman MW (2000) The MRP2/cMOAT transporter and arsenic-glutathione complex formation are required for biliary excretion of arsenic. J Biol Chem 275:33404-33408.

Khairul I, Wang QQ, Jiang YH, Wang C, and Naranmandura H (2017) Metabolism, toxicity and anticancer activities of arsenic compounds. Oncotarget 8:23905-23926.

Kimura A, Ishida Y, Hayashi T, Wada T, Yokoyama H, Sugaya T, Mukaida N, and Kondo T (2006) Interferon-gamma plays protective roles in sodium arsenite-induced renal injury by up-regulating intrarenal multidrug resistance-associated protein 1 expression. Am J Pathol 169: $1118-1128$.

Kimura A, Ishida Y, Wada T, Yokoyama H, Mukaida N, and Kondo T (2005) MRP-1 expression levels determine strain-specific susceptibility to sodium arsenic-induced renal injury between C57BL/6 and BALB/c mice. Toxicol Appl Pharmacol 203:53-61.

Kligerman AD, Doerr CL, Tennant AH, Harrington-Brock K, Allen JW, Winkfield E, PoormanAllen P, Kundu B, Funasaka K, Roop BC, et al. (2003) Methylated trivalent arsenicals as candidate ultimate genotoxic forms of arsenic: induction of chromosomal mutations but not gene mutations. Environ Mol Mutagen 42:192-205.

Kritharis A, Bradley TP, and Budman DR (2013) The evolving use of arsenic in pharmacotherapy of malignant disease. Ann Hematol 92:719-730.

Leslie EM (2012) Arsenic-glutathione conjugate transport by the human multidrug resistance proteins (MRPs/ABCCs). J Inorg Biochem 108:141-149.

Leslie EM, Bowers RJ, Deeley RG, and Cole SP (2003) Structural requirements for functional interaction of glutathione tripeptide analogs with the human multidrug resistance protein 1 (MRP1). J Pharmacol Exp Ther 304:643-653.

Leslie EM, Deeley RG, and Cole SP (2005) Multidrug resistance proteins: role of P-glycoprotein, MRP1, MRP2, and BCRP (ABCG2) in tissue defense. Toxicol Appl Pharmacol 204:216-237.

Leslie EM, Haimeur A, and Waalkes MP (2004) Arsenic transport by the human multidrug resistance protein 1 (MRP1/ABCC1). Evidence that a tri-glutathione conjugate is required. $J$ Biol Chem 279:32700-32708.

Loe DW, Almquist KC, Cole SP, and Deeley RG (1996a) ATP-dependent 17 beta-estradio 17-(beta-D-glucuronide) transport by multidrug resistance protein (MRP). Inhibition by cholestatic steroids. J Biol Chem 271:9683-9689.

Loe DW, Almquist KC, Deeley RG, and Cole SP (1996b) Multidrug resistance protein (MRP)mediated transport of leukotriene $\mathrm{C} 4$ and chemotherapeutic agents in membrane vesicles. Demonstration of glutathione-dependent vincristine transport. J Biol Chem 271:9675-9682.

Mass MJ, Tennant A, Roop BC, Cullen WR, Styblo M, Thomas DJ, and Kligerman AD (2001) Methylated trivalent arsenic species are genotoxic. Chem Res Toxicol 14:355-361.

Moe B, Peng H, Lu X, Chen B, Chen LWL, Gabos S, Li XF, and Le XC (2016) Comparative cytotoxicity of fourteen trivalent and pentavalent arsenic species determined using real-time cell sensing. J Environ Sci (China) 49:113-124.

Mukhopadhyay R, Bhattacharjee H, and Rosen BP (2014) Aquaglyceroporins: generalized metalloid channels. Biochim Biophys Acta 1840:1583-1591.

Naranmandura H, Carew MW, Xu S, Lee J, Leslie EM, Weinfeld M, and Le XC (2011) Comparative toxicity of arsenic metabolites in human bladder cancer EJ-1 cells. Chem Res Toxicol 24:1586-1596.

Naranmandura H, Ibata K, and Suzuki KT (2007) Toxicity of dimethylmonothioarsinic acid toward human epidermoid carcinoma A431 cells. Chem Res Toxicol 20:1120-1125.

Naujokas MF, Anderson B, Ahsan H, Aposhian HV, Graziano JH, Thompson C, and Suk WA (2013) The broad scope of health effects from chronic arsenic exposure: update on a worldwide public health problem. Environ Health Perspect 121:295-302.

Németi B and Gregus Z (2013) Reduction of dimethylarsinic acid to the highly toxic dimethylarsinous acid by rats and rat liver cytosol. Chem Res Toxicol 26:432-443.

Petrick JS, Ayala-Fierro F, Cullen WR, Carter DE, and Vasken Aposhian H (2000) Monomethylarsonous acid (MMA(III)) is more toxic than arsenite in Chang human hepatocytes. Toxicol Appl Pharmacol 163:203-207.

Platanias LC (2009) Biological responses to arsenic compounds. J Biol Chem 284: 18583-18587. 
Rahman MM, Ng JC, and Naidu R (2009) Chronic exposure of arsenic via drinking water and its adverse health impacts on humans. Environ Geochem Health 31 (Suppl 1):189-200.

Reay PF and Asher CJ (1977) Preparation and purification of 74As-labeled arsenate and arsenite for use in biological experiments. Anal Biochem 78:557-560.

Rehman K, Chen Z, Wang WW, Wang YW, Sakamoto A, Zhang YF, Naranmandura H, and Suzuki N (2012) Mechanisms underlying the inhibitory effects of arsenic compounds on protein tyrosine phosphatase (PTP). Toxicol Appl Pharmacol 263:273-280.

Roggenbeck BA, Banerjee M, and Leslie EM (2016) Cellular arsenic transport pathways in mammals. J Environ Sci (China) 49:38-58.

Shen S, Li XF, Cullen WR, Weinfeld M, and Le XC (2013) Arsenic binding to proteins. Chem Rev 113:7769-7792.

Shukalek CB, Swanlund DP, Rousseau RK, Weigl KE, Marensi V, Cole SP, and Leslie EM (2016) Arsenic triglutathione $[\mathrm{As}(\mathrm{GS}) 3]$ transport by multidrug resistance protein 1 (MRP1/ABCC1) is selectively modified by phosphorylation of Tyr920/Ser921 and glycosylation of Asn19/Asn23. Mol Pharmacol 90:127-139.

Smith AH, Lingas EO, and Rahman M (2000) Contamination of drinking-water by arsenic in Bangladesh: a public health emergency. Bull World Health Organ 78:1093-1103.

Stride BD, Grant CE, Loe DW, Hipfner DR, Cole SPC, and Deeley RG (1997) Pharmacological characterization of the murine and human orthologs of multidrug-resistance protein in transfected human embryonic kidney cells. Mol Pharmacol 52:344-353.

Styblo M, Del Razo LM, Vega L, Germolec DR, LeCluyse EL, Hamilton GA, Reed W, Wang C, Cullen WR, and Thomas DJ (2000) Comparative toxicity of trivalent and pentavalent inorganic and methylated arsenicals in rat and human cells. Arch Toxicol 74:289-299.

Suzuki KT, Tomita T, Ogra Y, and Ohmichi M (2001) Glutathione-conjugated arsenics in the potential hepato-enteric circulation in rats. Chem Res Toxicol 14:1604-1611.

Thomas DJ, Li J, Waters SB, Xing W, Adair BM, Drobna Z, Devesa V, and Styblo M (2007) Arsenic ( +3 oxidation state) methyltransferase and the methylation of arsenicals. Exp Biol Med (Maywood) 232:3-13.
Thomas DJ, Waters SB, and Styblo M (2004) Elucidating the pathway for arsenic methylation Toxicol Appl Pharmacol 198:319-326.

Vahter M (1999) Methylation of inorganic arsenic in different mammalian species and population groups. Sci Prog 82:69-88.

Wang QQ, Thomas DJ, and Naranmandura H (2015) Importance of being thiomethylated: formation, fate, and effects of methylated thioarsenicals. Chem Res Toxicol 28 281-289.

Wang Y, Chen M, Zhang Y, Huo T, Fang Y, Jiao X, Yuan M, and Jiang H (2016) Effects of realgar on GSH synthesis in the mouse hippocampus: involvement of system XAG(-), system XC(-), MRP-1 and Nrf2. Toxicol Appl Pharmacol 308:91-101.

Yang Y, Li Z, Mo W, Ambadipudi R, Arnold RJ, Hrncirova P, Novotny MV, Georges E, and Zhang JT (2012) Human ABCC1 interacts and colocalizes with ATP synthase $\alpha$, revealed by interactive proteomics analysis. J Proteome Res 11:1364-1372.

Yokohira M, Arnold LL, Pennington KL, Suzuki S, Kakiuchi-Kiyota S, Herbin-Davis K, Thomas DJ, and Cohen SM (2010) Severe systemic toxicity and urinary bladder cytotoxicity and regenerative hyperplasia induced by arsenite in arsenic ( +3 oxidation state) methyltransferase knockout mice. A preliminary report. Toxicol Appl Pharmacol 246:1-7.

Yokohira M, Arnold LL, Pennington KL, Suzuki S, Kakiuchi-Kiyota S, Herbin-Davis K, Thomas DJ, and Cohen SM (2011) Effect of sodium arsenite dose administered in the drinking water on the urinary bladder epithelium of female arsenic ( +3 oxidation state) methyltransferase knockout mice. Toxicol Sci 121:257-266.

Address correspondence to: Dr. Elaine M. Leslie, Department of Physiology, University of Alberta, 7-08A Medical Sciences Building, Edmonton, AB, Canada T6G 2H7. E-mail: eleslie@ualberta.ca 